Fall 12-3-2021

\title{
Change Project Using a Fall Prevention Action Program to Decrease Falls on a Behavioral Health Unit
}

Amy Shuptrine

University of St. Augustine for Health Sciences, a.shuptrine@usa.edu

DOI: https://doi.org/10.46409/sr.JFXX6423

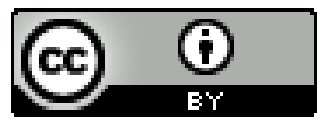

This work is licensed under a Creative Commons Attribution 4.0 License.

Follow this and additional works at: https://soar.usa.edu/scholprojects

Part of the Psychiatric and Mental Health Nursing Commons, Psychiatry and Psychology Commons, and the Quality Improvement Commons

\section{Recommended Citation}

Shuptrine, A. (2021). Change Project Using a Fall Prevention Action Program to Decrease Falls on a Behavioral Health Unit. [Doctoral project, University of St Augustine for Health Sciences]. SOAR @ USA: Student Scholarly Projects Collection. https://doi.org/10.46409/sr.JFXX6423

This Scholarly Project is brought to you for free and open access by the Student Research at SOAR @ USA. It has been accepted for inclusion in Student Scholarly Projects by an authorized administrator of SOAR @ USA. For more information, please contact soar@usa.edu, erobinson@usa.edu. 
Change Project Using a Fall Prevention Action Program to Decrease Falls on

\section{a Behavioral Health Unit}

Amy Shuptrine, MSN, APRN, FNP-BC

School of Nursing, University of St Augustine for Health Sciences The

Manuscript Partially Fulfills the Requirements for the

Doctor of Nursing Practice Program and is Approved by:

Mary Brann, DNP, RN

Donald Hunt, PhD, RN

Approved: December 3, 2021 


\begin{abstract}
Practice Problem: Fall rates are increasing in the behavioral health units of the East Texas hospital. Due to the worldwide COVID-19 pandemic, the units are short-staffed, which further supports the urgent need for a targeted intervention to reduce fall risk.

PICOT: The PICOT question that guided this project was: "In adult behavioral health patients (P), what is the effect of the Edmonson Psychiatric Fall Risk Assessment Tool (I), compared with previous use of the Morse Fall Risk tool $(\mathrm{C})$, on the fall rate $(\mathrm{O})$, in 8 weeks $(\mathrm{T})$ ?”

Evidence: Falls are the most reported incidents in acute care hospitals and falls of behavioral health patients are more challenging to mitigate than those of other patients. Evidence suggested that the Edmonson Psychiatric Fall Risk Assessment Tool aided in identifying and mitigating fall risks by tailoring care plans to individual patients.

Intervention: The Edmonson Psychiatric Fall Risk Assessment Tool was completed on every patient over the age of 18 years, which was admitted, discharged, falling, or had a change in condition, while on the psychiatric unit. The risk assessment was used to determine the risks and other factors that contribute to the patient falling. Once the contributors were identified, the data was used to put interventions into place and revise each individualized care plan to decrease falls.
\end{abstract}

Outcome: The intended outcome was to identify patients that were at substantial risk for falls using the EPFRAT tool, mitigate some of their risks, and therefore decrease falls.

Conclusion: Continued emphasis on the fall risks of behavioral health patients will be paramount in the management and success of the continued improvement in patient outcomes. 


\section{Change Project Using a Fall Prevention Action Program to Decrease Falls on a Behavioral Health Unit}

Every year one of the greatest threats to hospitalized patients in the United States is falling. Falls remain the number one reason for death preceded by severe injury in the elderly population (Blair \& Szared, 2008). Studies have determined that falls among psychiatric or psychogeriatric patients are prevalent due to psychiatric medications, independent living, sedative medications, restriction of restraints, and the ability to ambulate freely (Mathew et al., 2020). Psychotropic medications increase the incidence of falls by $20 \%$ (Blair \& Szared, 2008).

This project implemented a fall prevention program to decrease falls and help prevent injuries and mortality related to falls. The primary intervention associated with the program was Edmonson Psychiatric Fall Risk Assessment Tool, or EPFRAT (Mathew et al., 2020). The data collected from the assessment tool was used to develop an individualized care plan for each patient to decrease falls.

\section{Significance of the Practice Problem}

Throughout the world, 646,000 falls occur annually, and 30\% of those individuals sustain a serious injury (World Health Organization [WHO], 2017). Falls are the second leading cause of preventable death (WHO, 2017).

Each year in the United States, over 700,000 people suffer from falls during hospitalization (Agency for Healthcare Research and Quality, 2020). In 2014, there were 36, 337 falls in Texas involving hospitalized patients, and 3\% of those patients died (Texas Health and Human Services, 2017, p. 2). Of all the deaths related to falls, $48 \%$ of those were from traumatic 
brain injury (TBI) (Texas Health and Human Services, 2017). With staggering statistics like this is not surprising to learn that $16 \%$ of all falls led to TBI (Texas Health and Human Services, 2017). Northeast Texas ranks $34^{\text {th }}$ among the Texas regions in deaths attributed to unintentional incidents such as falls (UT Health Systems, 2016).

Falls lead to negative outcomes such as injury, disability, death, and legal liability issues (Jabbarpour, 2017). The human cost of an accidental fall is quite devastating. Depression, decreased self-confidence, pain, injury, increased long-term or chronic conditions, loss of jobs, and death can all be caused by a fall event (NHS Improvement, 2017). Families may also pay the price with increased burden, financial obligations regarding prolonged hospital stays and rehabilitation, depression, uncertainty, and grief (NHS Improvement, 2017). A fall can lead to as many as 6.9 additional days in the hospital and cost \$14,000 per incident (NHS Improvement, 2017).

On the behavioral health unit where the new tool was implemented there had been an increase in falls. Over $1 / 3$ of the falls on this unit in the last year had occurred in the 3 months prior to project implementation. One patient suffered a cervical spine fracture. According to the unit supervisor, falls have always been a major concern, especially since the use of the Morse Fall Scale does not consider areas of concern for this population. Items such as high-risk medications and sleep disturbance are not addressed on the Morse Fall Scale and the number of falls in the unit continues to climb.

\section{PICOT Question}

Falls are a continuing issue for hospitals. They have a significant impact on patients, families, and the organization. Many factors contribute to falls, such as pain, confusion, delirium, 
inappropriate footwear, and medications. Since hospitalized behavioral health patients present with many of these factors, the population suffers a significant number of falls. Studies show that geriatric psych patients have more severe injuries related to falls than adult psych patients(Turner et al, 2020). A valid, reliable assessment can be used to identify fall risk so that individuals can be protected from falls? Therefore, to identify the best assessment to reduce fall risk in the target population, the question regarding population, intervention, comparison, outcome, and time (PICOT) was: In adult behavioral health patients (P), what is the effect of the Edmonson Psychiatric Fall Risk Assessment Tool (I), compared with previous use of the Morse Fall Risk tool $(\mathrm{C})$, on the fall rate $(\mathrm{O})$, in 8 weeks $(\mathrm{T})$ ?

This project was applied to an adult behavioral health unit that serves patients over the age of 18 years old. The EPFRAT was completed for each patient upon admission, daily, after each fall incident, anytime there was a change in patient condition and upon discharge from the hospital (ACT Government Health, 2019). The resulting data was then used to create an individualized plan of care for patients and to decrease their fall incidents (Edmonson, n.d.). This intervention was implemented and compared to the previous use of the Morse Fall Scale, over 8 weeks.

\section{Evidence-Based Practice Framework and Change Theory}

The Johns Hopkins Evidence-Based Practice (EBP) Model is simply the problem, evidence, and translation (PET) process that is a proven approach to drive this practice change project (Johns Hopkins Medicine, n. d.) (Howe \& Close, 2016). The first step in this model was to bring together the interdisciplinary team (IDT) that will meet to identify a problem that the facility is facing and work to develop a practice question (Howe \& Close, 2016). The newly 
developed question was taken to the research to collect evidence of what was known in the literature about the problem and report back to the IDT (Howe \& Close, 2016). The IDT then synthesized the information collected to make suggestions regarding the practice change project that was implemented (Howe \& Clarke, 2016). Once the project was completed, the information was used to translate the data into practice (Johns Hopkins Medicine, n.d.).

The change theory that best complemented this project was John Kotter's eight-step change model (Aziz, 2017). The steps in this model are as follows: 1) create a sense of urgency by showing the staff the significance of the problem, 2) form a powerful coalition by getting buy-in from the staff, not just the IDT, 3) create the vision for change with a purpose and a goal in mind, 4) consistently communicating the vision and answering questions, 5) empower the staff for action, 6) create quick wins with short-term easy to achieve goals, 7) build on change, do not back off too soon, and 8) make change stick with senior staff supporting and helping to sustain it (Aziz, 2017). Kotter's change model was used to engage the staff, promote continued adherence, and to ensure sustained deployment of the practice change with continued leader support (Frieson et al., 2012).

\section{Evidence Search Strategy}

When searching for information related to the PICOT question, the search engines utilized were PubMed and Google Scholar. The terms used were accidental falls, psychiatry, and risk assessment. The inclusion criteria were all scholarly articles, studies, journals, and information pages that discussed the use of the Edmonson Psychiatric Fall Risk Assessment Tool, falls in psych and Geri-psych patients, falls related to psychogenic medications, and inpatient deaths related to falls in Texas, the US, and globally, written in the last five years. 
Some of the tactics used to render good search and limit results were adding the Boolean connector word "and" between the different words and using quotation marks.

The search results that were rendered were as follows: PubMed 83 citations, Google Scholar had 245 citations, and ProQuest yielded 20,355 so, the word inpatient was added. This decreased search results to 185 . Articles were reviewed for quality, duplicates removed, and all information that was not full text, which listed pediatric patients, or was not in English were excluded. There were six articles hand-selected due to their relevance to the project.

\section{Evidence Search Results}

In conducting the literature search for articles related to the PICOT question using the search databases of PubMed, Google Scholar, and ProQuest. The database results were 513 journal articles and 245 articles through Google Scholar. Each search term and different combinations of the terms were used rendering the aforementioned numbers. The total number of articles was. After all the 442 duplicates were removed, there were 71 articles left for screening (University of North Carolina Library of Health Sciences (UNC), 2021).

Many exclusions were made to the list of documents to narrow the search of evidence. Exclusions made to narrow searches were articles that did not lend helpful information to the PICOT question (UNC, 2021). Articles were excluded that were not in the right timeframe. Articles about patients in the home setting were excluded. Any adverse event of a psych or Geri psych patient that were unrelated to falls caused by trip hazards falls in pediatric patients and articles of the wrong population were excluded as well.

The next step was to screen the articles for information that will help to support the research question (UNC, 2021). The Johns Hopkins Evidence-Based Practice tool to determine 
level If the article did not support the research question it was then excluded as well (UNC, 2021). Next, articles that were not full text were excluded (UNC, 2021). There is not enough pertinent information to deduce from an abstract. When the total number of articles that are not full text are subtracted from the total number of articles that met eligibility criteria only qualitative articles are left for review (UNC, 2021).

The final number of articles used to support the evidence is six full-text articles. Using the Johns Hopkins Evidence-Based Practice Model level and quality guide the articles that were remaining after exclusion were given a level and a grade according to the type and extent of study. All the studies reviewed were a Level II except for the EPFRAT study which is a nonexperimental study that, according to the Johns Hopkins level and quality guide, makes it a Level III (Johns Hopkins Hospital, n.d.). Each of the studies is Graded: High due to the extent of information presented (Johns Hopkins Hospital, n.d.).

\section{Themes with Practice Recommendations}

In making a case for a change project it is important to review the literature, analyze, and synthesize the information. One must determine the most prominent themes that drive the project, as well as articulate the recommendation that will help to make the project successful. of them recognize the fact that falls among inpatients are a significant problem that has a huge negative impact on a patient's mobility and mortality (Wang et al., 2019). Two of the articles

point out that not only are fall events of detriment to the patient but it brings financial strain to the facilities as well (Morici et al., 2021). According to the literature, a fall potentially adds 6.9 additional days to a patient's length of stay (LOS) (NHS Improvement, 2017). These added days 
are for further radiologic studies, diagnostic studies, and treatments, all related to injuries sustained from a fall (Morici et al., 2021).

Although inpatients are at higher risk than the community to have falls, psychiatric patients, especially those over 65-year-old are at the highest risk (Wang et al., 2021). There are many contributing factors that elderly patients contend with that increase their risks such as frailty, functional disorders, gait, and balance issues (Wang et al., 2021). Five of the six articles analyzed point out that psychiatric or behavioral health patients are at the highest risk due to mental instability, dementia, altered mental status, sleep disturbances, mental lability, and in most cases psychotropic medications (Janus et al., 2017).

\section{Risk Assessment Tool}

If one refers to the literature reviewed for this project, they will see that it is strongly recommended to apply a process that assesses the fall risk of the patient to determine what outside factors attribute to each fall and to develop and implement a process to avoid falls (Morici et al., 2021). So, if we know that most falls are preventable and that outside factors such as medications can be the biggest issue for these patients, then what is the solution?

There were six studies after all the other articles were excluded and they are referenced in Appendix B. Of these six studies, four of the studies agree that using a fall risk assessment tool to identify patients at high risk for falls and to implement interventions to mitigate falls for behavioral health patients is key (Morici et al., 2021). All four of these studies recommended some type of risk assessment tool to determine risk factors and mitigate risks. Two of the studies used the EPFRAT even if in correlation with another tool. According to the literature not only is 
the EPFRAT user-friendly but it is also preferred over the Morse Fall Scale (Bosse \& LaPoint, n.d.; Mathew et al., 2020).

\section{Medication Assessment}

One study used the EPFRAT in conjunction with the Wilson Sims Fall Risk Assessment Tool (WSFRAT) to make one tool. The biggest reason was to incorporate the questions about medications (Morici et al., 2021). EPFRAT also has questions related to medications when many other fall risk assessment tools do not. For psychiatric patients this cannot be overlooked. As the literature pointed out, psychotropic medications are the main factor to blame for the increased risk of falls (Wang et al., 2021). Of the six studies, three studies highlight the fact that several different classes of medications can contribute to falls especially in the elderly (Janus et al, 2017).

While four of the six studies highlight the fact that psychotropic medications are at the epicenter of factors that are causing psychiatric patients to have increased risk for falls, one study analyzes data regarding not just psychotropic drugs in general but specific categories of psychotropics (Janu et al., 2017). According to the study hypnotics and sedatives are the biggest culprit (Janus et al., 2017).

\section{Patient-Centered Care}

Each patient has their own set of risk factors. Determining what those were and addressing them on an individual basis helped to avoid falls by decreasing the fall risks. While some risks could be mitigated, others such as age, sex, and comorbidities cannot. Making the proper adjustments for those that could, were meant to help reduce falls and all the negative outcomes from fall incidents (Janus et al, 2017; Wang et al, 2021; Bosse \& LaPoint, n.d.; 
Mathew et al, 2020). Using a risk assessment score to customize a patient's care based on their individual needs has been shown, in the literature to be successful in addressing many issues that have negative outcomes and one of the biggest falls and injures from falls (Janus et al, 2017; Wang et al, 2021; Bosse \& LaPoint, n.d.; Mathew et al, 2020).

When addressing a patient's individualized plan of care in conjunction with a fall risk assessment, the IDT can consider many of the factors that make the patient fall risk. With a tool such as the EPFRAT, major players such as medications and sleep disturbances are added to previously considered factors such as age and cognition (Morici et al, 2021; Bosse \& LaPoint, n.d.; Mathew et al, 2020).

\section{Practice Recommendations}

The themes identified were decreasing falls with the help of a risk assessment tool, medication review, and patient-centered care to aid in mitigating the risk of falls in this population. All these issues directly address the PICOT question and build a strong case to proceed with the change project to decrease falls in the psychiatric or Geri-psych inpatient units using the EPFRAT (Mathew et al., 2020).

\section{Setting, Stakeholders, and Systems Change}

The setting of this DNP project is a behavioral health unit at a 425-bed hospital. This behavioral health unit is a 10-bed unit of patients admitted with one or more psychiatric diagnoses and requiring at least one psychiatric medication. The patients were adults, all over 18 years of age. In caring for these patients and putting interventions into place to decrease falls, the hospital's vision and mission was met. Their mission is " to serve the region and beyond through excellent patient care and community health, comprehensive education, and innovative research" 
and the vision is "to be a great institution, unified in common purpose, to benefit human health and to improve quality of life" (UT Health Northeast, 2021).

The number of falls and injuries related to falls on this unit had grown over several months preceding the project. During the Risk Management and Quality Performance meetings, risk management reports were run, and revealed that falls on this unit were at the forefront of issues that needed to be addressed to improve patient outcomes. In the 90 days prior, there were 11 falls with 1 severe injury. In the last year, there had been 30 falls, $66 \%$ of those were in the last six prior to beginning the project.

\section{Stakeholders}

The project was overseen by the project manager. The major stakeholders are the patients, the Chief Nursing Officer (CNO), the unit director, the charge nurse, unit clerks, the unit nurses, program champions, and the patient care associates (PCA). After the project manager presented the information to the stakeholders for buy-in the project implementation began.

\section{Sustainability}

Meetings were held with the CNO and the unit directors to discuss the aim of the project. The specifics of the Edmonson Psychiatric Fall Risk Assessment Tool (EPFRAT) were discussed in detail. The $\mathrm{CNO}$ and the unit supervisors were in agreeance on moving forward with the change project. There were necessary meetings held with the CFO, CNO, and department heads to present the project. Meetings were conducted with the staff to discuss the dire need for the project, training, statistics of the problem, and projected outcomes. These meetings were vital to attain buy-in from the staff. Making sure the staff nurses felt confident in the use of the 
assessment tool and supporting them throughout the process, frequent follow-up with project data, as well as the simplicity of the tool helps to ensure future sustainability.

\section{Strengths, Weaknesses, Opportunities, and Threats}

A SWOT analysis was completed to determine strengths, weaknesses, opportunities, and threats to the project (Appendix B) (Brandenburger, 2019). It is important to identify the internal strengths and weaknesses and search the external opportunities and threats; using the information from all four sectors of the SWOT matrix a strategic plan is written for implementation (Brandenburger, 2019).

The level of change for this project meso-level, which includes teams, groups, units, and organizations (Jilke et al., 2021). The data was synthesized appropriately, the stakeholders educated, buy-in established, a plan was written according to the SWOT analysis, and the project plan was successfully implemented.

\section{Implementation Plan with Timeline and Budget}

Once the proposal for the change project proposal was completed it was submitted to The University of St Augustine for Health Sciences faculty or approval. The project was then evaluated for clinical significance and appropriateness to the DNP scholarly project and its translation into prudent practice.

Once approval was derived from the university the project manager then moved forward in attaining approvals from the hospital's EPRC, Chief Nursing Officer (CNO), Chief Financial Officer (CFO), nursing department heads, and Quality Assurance leaders. The proposal was presented to these leaders congruently by the project manager during a scheduled meeting where the project manager was present to answer questions and discuss the objectives of the project. 
The budget items were discussed with the CFO for consideration. The budget items considered were training hours for the champions, nursing staff training, ward clerk time for copying EPFRAT, hours for the QA nurse to audit and chart findings, supplies such as printer paper and ink, as well as staff time for scheduled meetings (Appendix A).

According to the Johns Hopkins EBP model securing the necessary support and resources to implement the project is an important step in managing a project for successful plan translation (Johns Hopkins Medicine, n.d.).

The next step was reflective of Kotter's change model and describes how the steps in this model support the implementation of the project. The project manager met with stakeholders including staff to discuss the urgency of the problem, form a strong team while getting buy-in, open lines of communication, plant the seed of change with specific goals in mind, and to empower the staff during this process (Aziz, 2017). An interdisciplinary approach with all staff and patients from the unit helped to guide the project and promote positive patient outcomes. All the aforementioned steps are the backbone to staff buy-in and are the first five principles of the eight principles in John Kotter's change model (Aziz, 2017).

During this meeting, the department heads were to establish project champions to help train the nurses on the use of the EPFRAT. It was decided by admin instead that the project manager would be the designated person to complete the EPFRAT assessments as needed. The five days dedicated to the project manager training champions was surpassed. Time was spent with the nursing staff familiarizing them with the tool and how the tool would be used to determine appropriate interventions. Giving the nurses the knowledge to use the tool gave them a support system, empowered them to recognize a patient at high risk for falls and act to prevent 
falls. The nurses and PCAs made copies of the EPFRAT which was utilized upon admission, after every fall, with a change of patient condition, and upon discharge of every patient that is over 18 years of age admitted to the behavioral health unit. Exclusions were any patient younger than 18 years old or patients that were not admitted as inpatients to the behavioral health unit.

The EPFRAT has been rated as simple to use, by nurses who have used it, versus the Morse Fall Risk Scale (Mathew et al., 2020). One objective of this project was to determine if this tool is more specific to fall risks in the psychiatric population versus the Morse Scale. The fact that the Morse Scale does not even address medications, but does look at IV access, brings to question if the Morse Scale is geared more toward the medical-surgical or intensive care units.

Another objective of this project was the identification of $100 \%$ of patients at high risk for falls with an EPFRAT score of $\geq 90$, which identifies them as a high risk for falls. Being aware that these patients were high risk allowed for nurses and staff to implement interventions such as 15-minute rounding, care plan review with the team, medication reviews, and walkway clearing, to name a few (Appendix I).

The last objective of this project, yet the most important, was to decrease falls by at least $10 \%$ in eight weeks. With falls remaining the number 1 reported event in the inpatient setting and deaths related to falling sustained injuries in the elderly being the number 1 accidental death, it makes perfect sense to implement a project to decrease falls on hospitalized patients (Ocker et al., 2020; Mathew et al., 2020).

The charge nurse reviewed risk management reports and charts daily. She reported to the project manager weekly with findings. She audited for compliance with the use of the tool to identify patients with fall risk, she tracked all falls sustained in the unit and injuries or deaths 
from falls. This data was compiled and emailed to the staff by the project manager every two weeks. At the end of the project, which ran a duration of eight weeks, the final numbers and data were delivered to the department heads by the project manager. The meeting was held to discuss the findings and any gaps or issues with the project.

One risk to this project was the clear understanding across staff members about what is considered a fall. If a patient is to stumble and fall into a chair without injury that is still a fall. Mitigating this issue was done by educating the staff in the beginning what constituted a fall (Bosse \& LaPoint, n.d.). Another threat to the project was a discrepancy in the falls reported and the falls that a were documented. To help alleviate this issue, any report of a fall, the nurse or charge nurse was to immediately go to the patient, and once the patient was safe and had received appropriate care an incident report was started.

\section{Results}

All the measures of this project were collected from the facility electronic medical record (EMR) system, and the EPFRAT (Appendix F). The clinical supervisor monitored the fall risk reports and provided copies to the project manager. The project manager completed the EPFRAT on all patients as indicated and audited charts for consistency of the use of the tool. All adult patients were included, and no adult patient was excluded. The EPFRAT was completed on paper, and any patients that flagged as a fall risk had their charts flagged as a fall risk for interventions.

The unit was monitored for eight weeks to determine if using the EPFRAT versus the Morse Fall scale was better at identifying patients at risk for falls and in turn decreasing their fall incidences on a behavioral health unit. The hospital's EMR system was able to produce patient 
fall totals with fall reports, risk management materials, injuries related to falls, age, gender, and medication lists.

The data was entered weekly on the Fall Rate Tool (Appendix H) and discussed in the report. The information on the tool that was collected for reporting was gender, age, EPFRAT score, the number of falls sustained, the number of falls with significant injury, the total number of falls weekly, and the total number of falls in 30 and 60 days (Appendix H). Reports of the findings were emailed to stakeholders every two weeks and final reporting was held with the project managers, $\mathrm{CNO}$, and stakeholders at a scheduled staff meeting at the end of the project.

Data analysis was completed by the project manager while utilizing the Intellectus Statistics software. The University of St. Augustine for Health Sciences has given each student access for use of this tool. HIPPA compliance was preserved according to federal law and hospital policy. No identifying information was used in the reporting and collecting of the information. The data was be secured on the project manager's laptop which requires a security password to log in and is kept in a locked safe at the project manager's home.

\section{Fall Rates}

A two-tailed independent t-test was completed and deemed not significant based on alpha value of $0.05, t(68)=-0.86, p=.392$. So according to these findings, the null hypothesis cannot be rejected. Cohen's d is 0.2 meaning there may be a small improvement post-test. Any necessary data not recorded will be marked as inconsistency with the assessment tool use.

\section{Table 1}

Two-Tailed Independent Samples $t$-Test for Number_of_Falls by Time_Period

$$
\text { Pre-test Post-test }
$$

\begin{tabular}{lllllll}
\cline { 2 - 3 } & $M$ & $S D$ & $M$ & $S D$ &
\end{tabular}$\quad d$


$\begin{array}{llllllll}\text { Number_of_Falls } & 0.23 & 0.58 & 0.40 & 1.10 & -0.86 & .392 & 0.20\end{array}$

Note. $\mathrm{N}=70$. Degrees of Freedom for the $t$-statistic $=68 . d$ represents Cohen's $d$.

\section{Balancing and Budget}

During the implementation phase, it was determined by the behavioral health administration that the EPFRAT assessment would be completed by the project manager as the hospital was unable to receive approval for the use of the Edmonson tool. Considering this and the fact that they would soon roll out a new EMR system, the hospital chose to use the Johns Hopkins Fall Risk Assessment Tool (JHFRAT). The administration no longer found it valuable for the nurses to complete the EPFRAT and MORSE tools until the new system was implemented.

Due to the deviations from the original plan the only budget items that were used as printing materials, staff to make copies, and nursing hours to educate and discuss the project. There were no other staffing, supply, or EMR expenses.

\section{Outcome}

The clinical significance of this project is to use evidence-based practice by using the EPFRAT to decrease falls in an inpatient psychiatric unit. The unit currently uses the Morse fall scale; however, the evidence suggests that this fall assessment is not the most adequate for psychiatric patients. When compared, the EPFRAT rated $80 \%$ more sensitive and $96 \%$ more specific at predicting fall risk in psychiatric patients than with Morse (Bosse \& LaPoint, n.d.). Reliability has been tested using Cronbach's alpha with an alpha score of 92\%. Of the nurses that used it for the study, $80 \%$ stated it had great usability and $87.5 \%$ agreed it was completely relevant to psychiatric patients and gave it a good rating (Mathew et al.,2020). 
The financial benefits of the success of this project are to decrease falls and in doing so saving the institution $\$ 14,000$ or more per fall incident (NHS Improvement, 2017). Each fall that a patient sustains can potentially increase their length of stay by 6.9 days, which is financially stressful on patients, facilities, and insurance companies alike.

\section{Sustainability}

The ease of use of this tool and implementing this tool to the EMR as part of the daily assessment made it easily sustainable. The facility uses HealthStream for required training so implementing this tool through this type of training would be beneficial for all psychiatric patients. Chart audits for continued monitoring will help ensure the appropriate use of the tool.

This practice change project proposal was presented first to the DNP faculty at The University of St Augustine for Health Sciences for approval to present to the facility. The proposal was then presented to the CNO, EPRC, and CFO for approval to proceed.

\section{Impact}

This project had a positive impact on the unit nurses and ancillary staff. Before this project was implemented, the staff nurses admitted that they had not given much thought to the difference that an assessment tool, more dedicated to the psychiatric population, could make. There were discussions about the findings of the EPFRAT and the drastic differences compared to the Morse fall scale. The project prompted more discussions between the staff and the project manager regarding patients' change of condition, medication changes, and new falls. The staff familiarized themselves with the issues that affected the fall assessment score and patient care acuity. 
This project would have been much more successful if the EPFRAT tool could have been used by the nursing staff solely, and they had not been made to continue using the Morse Fall scale. The positive impact of this tool was acknowledged by both staff and administration, but due to the fact they had originally decided to move forward with the JHFRAT over the EPFRAT, management felt it would be too time-consuming and stressful to learn one tool and then switch to another in just a few weeks.

Implementing the EPFRAT did start the discussion and draw attention to the need for a more appropriate fall risk tool for psychiatric patients on the unit. This need prompted the request for a better assessment tool and helped the administration agree to implement a tool more dedicated to psychiatric patients. Per the $\mathrm{CNO}$, due to the findings of the project the facility was prompted to again apply for approval to use the EPFRAT. The tool was added to the EMR system and went live 3 weeks after the completion of this project. Having this tool as part of the daily assessment and part of the fall incident reports made it easily sustainable.

Continued close monitoring of the psychiatric and Geri-psych units for fall rates will be necessary to determine if the fall risk assessment tool is being completed when warranted. Use of the tool to put interventions into place to keep patients from falling and adjusting individual care plans to reflect the needs of the patient is the ultimate goal. Healthier patients mean happier patients and that means higher patient satisfaction ratings.

\section{Dissemination Plan}

The priority to ensure dissemination of the project was to share the information with the stakeholders, the CNO, unit administration, unit nurses, and ancillary staff. The project findings were related for internal dissemination at an in-person meeting to go over data. The presentation was delivered as a PowerPoint presentation with accompanying handouts so that stakeholders 
would have a good understanding of the project outcomes and gaps in practice. The nursing leadership disseminated the data to the staff unable to make the face-to-face meeting due to scheduling conflicts. The data was emailed to the department leaders for unit dispersal.

This project was submitted to the Scholarship and Open Access Repository website at the University of St. Augustine for Health Sciences (SOAR@USA). There are plans for the project manager to disseminate findings at the monthly East Texas Nurse Practitioner Association conference. The completed PowerPoint presentation was made to educate advanced practice nurses on the use of the EPFRAT tool for decreasing falls in the psychiatric population.

Ultimately, the goal is to submit the EPFRAT project to The Journal of Nursing Administrators (JONA) for publication. This journal is geared toward nurse managers, directors, and executives to guide their practice with the newest, cutting-edge advancements in practice (Hill, 2021). JONA has been around for over fifty years and is a peer-reviewed journal. Their editorial board selects articles that are ingenious, solution-centered, and evidence-based information, which can be used by nurse leaders to improve patient outcomes and the whole patient experience (Hill, 2021).

\section{Conclusion}

Prevention of falls in geriatric psychiatric patients was the main objective of this project. Patients at the highest risk for falls were identified using the EPFRAT tool and that information was used by the nursing staff to update and revise patient care plans to decrease the patient's chances for falls on the psychiatric unit (Mathew et al., 2020). The project reflected the Johns Hopkins EBP process for putting change into place to decrease falls as falls remain the leading cause of accidental injury in Texas and the U.S. (Johns Hopkins, n.d.) (Texas Health and Human 
Services, 2017, p.1). Among such falls the greatest incidence is in adults over the age of 65 (Texas Health and Human Services, 2017, p.2). Psychiatric patients make up many of these falls due to their overall mental state, sleep deprivation, and psychotropic medications (Janus et al, 2017).

Most fall risk assessment tools are generalized and do not address medications which makes them less effective in preventing falls in this population. The project followed John Kotter's eight-step change model to earn buy-in, train staff, and make system changes to improve patient outcomes (Aziz, 2017). The ease of the use of the EPFRAT, the competency of the nursing staff, as well as decrease in the use of resources and hospital days sustained this project and promoted better patient outcomes (Mathew et al., 2020).

\section{References}

ACT Government Health. (2019). Falls prevention and management: Including safe use of bed rails. https://health.act.gov.au

Agency for Healthcare Research and Quality. (2020). A patient-centered fall prevention tool kit. https://www.falltips.org/implement-fall-tips/step-1/

Aziz, A. M. (2017). A change management approach to improving safety and preventing needlestick injuries. Journal of Infection Prevention, 18(5), 257-262. https://doi.org/10.1177/1757177416687829

Blair, E.W, \& Szared, B. L. (2008). Exploring the relationship of psychotropic medications to fall events in an inpatient geriatric psychiatric population. International Journal of Psychiatric Nursing Research, 14(1), 1698-1710.

Bosse, J., \& LaPoint, C. (n.d.) Sensitivity and specificity of the Edmonson Psychiatric Fall Risk 
Assessment Tool in an adult inpatient psychiatric unit. UMASS Amherst College of Nursing. https://sigma.nursingrepository.org/bitstream/handle/10755/603255/1_Bosse_J_ p70991_2.pdf?sequence=1\&isAllowed=y

Brandenburger, A. (2019, August 22). Are your company's strengths weaknesses? Harvard Business Review. https://hbr.org/2019/08/are-your-companys-strengths-reallyweaknesses

Edmonson, D. (n.d.). Edmonson Psychiatric Fall Risk Assessment Tool. Memorial Health System. https://www.memorialmedical.com/services/behavioralhealth/edmonsonpsychiatric-fall-risk-assessment

Frieson, C.W., Foote, D.G., Frith, K.H., \& Wagner III, J.H. (2012). Utilizing change theory to implement a quality improvement, evidence-based fall prevention model in long-term care. Journal of Gerontology \& Geriatric Research, S1(001), 1-7. https://doi.org/ 10.4172/2167-7182.S1-001

Howe, C.J., \& Close, S. (2016). Be an expert: Take action with evidence-based practice. Journal of Pediatric Nursing, 31(3), 360-362. https://www.pediatricnursing.org/article/S0882$\underline{5963(16) 00056-7 / \text { fulltext }}$

Jabbarpour, Y. (2017). Improving safety in health care for patients with neurocognitive disorders and high risk of falls. Focus Psychiatry, 15(1), 68-74. https://focus.psychiatryonline.org/doi/pdf/10.1176/appi.focus.20160038

Janus, S., Reinders, G. H., van Manen, J. G., Zuidema, S. U., \& IJzerman, M. J. (2017). Psychotropic drug-related fall incidents in nursing home residents living in the eastern part of The Netherlands. Drugs in R\&D, 17(2), 321-328. https://doi.org/10.1007/s40268$\underline{017-0181-0}$ 
Jilke, S., Olsen A. A., Resh, W., \& Siddikki, S. (2021). Analytic frameworks for micro-, meso-, and macro-level public administration. Syracuse University. https://www.maxwell.syr.edu/minnowbrook/about/analytic-frameworks-for-micro$\underline{\text { mesoand-macro-level-public-administration/ }}$

Johns Hopkins Hospital. (n.d.). Johns Hopkins nursing evidence-based practice Appendix c: Evidence level and quality guide. Johns Hopkins University. Retrieved month date, year, from https://www.hopkinsmedicine.org/evidencebasedpractice/_docs/SW_c_evidence_level_quality_guide.pdf

Johns Hopkins Medicine. (n.d.). Center for evidence-based practice. https://www.hopkinsmedicine.org/evidence-based-practice/ijhn_2017_ebp.html

Lansing Community College. (n.d.). Nursing: PICOT. LCC Home. https://libguides.lcc.edu/c.php?g=167860\&p=6198388

Mathew, L., Steigman, D., Driscoll, D., Moran-Peters, J., Fischer, I. M., Cordle, P., \& Eckardt, S. (2020). Making fall risk assessment clinically relevant in an adult psychiatric setting. Journal of Psychosocial Nursing \& Mental Health Services, 58(2), 21-26. https://doi.org/10.3928/02793695-20191106-01

Morici, V., Terzoni, S., Ferrara, P., \& Destrebecq, A. (2021). Development and validation of a new tool for assessing the risk of falls in acute psychiatric settings. International Journal of Emergency Mental Health and Human Resilience, 18(2), 742-747. https://www.omicsonline.org/open-access/development-and-validation-of-a-new-toolforassessing-risk-offalls-in-acute-psychiatric-settings-1522-4821-1000330.pdf

NHS Improvement. (2017). The incidence and costs of inpatient fall in hospitals. Falls_report_July2017.v2.pdf (improvement.NHS.uk) 
Ocker, S. A., Barton, S. A., Bollinger, N., Leaver, C. A., Harne-Britner, S., \& Heuston, M. M., (2020). Preventing falls among behavioral health patients. American Journal of Nursing, 120(7), 61-68. DOI: 10.1097/01.NAJ.0000688256.96880.a3

Texas Health and Human Services. (2017). Unintentional falls among adults aged 65 years and older in Texas. https://www.dshs.texas.gov/injury/data/Falls-Injury-Data-Brief.pdf

Hill, K. S. (2021). Innovations in Healthcare Executives leadership and management. The Journal of Nursing Administration, 51(10), 1-531. https://journals.lww.com/jonajournal/pages/currenttoc.aspx

Turner, K., Bjarnadottir, R., Jo, A., Repique, R. J. R., Thomas, J., Green, J. F., \& Staggs, V. S. (2020). Patient falls and injuries in US psychiatric care: Incidence and trends. Psychiatric Services, 71(9), 899-905. https://doi.org/10.1176/appi.ps.202000004

University of North Carolina Library of Health Sciences. (2021). Creating a PRISMA flow diagram. https://guides.lib.unc.edu/prisma

UT Health Northeast. (2021). Mission \& Vision. https://www.uthct.edu/mission-vision/ UT Health Systems. (2016). The health status of northeast Texas. UT Health and Science Center. https://utsystem.edu/sites/default/files/news/assets/northeasttx-health-status-report2016.pdf

Wang, K. N., Bell, J. S., Gilmartin-Thomas, J. F. M., Tan, E. C. K., Cooper, T., Robson, L., \& Ilomäki, J. (2021). Use of falls risk-increasing drugs in residents at high and low falls risk in aged care services. Journal of Applied Gerontology, 40(1), 77-86. https://doi.org/10.1177/0733464819888848

World Health Organization. (2018). Falls. https://www.who.int/news-room/fact$\underline{\text { sheets/detail/falls }}$ 


\section{Appendix A}

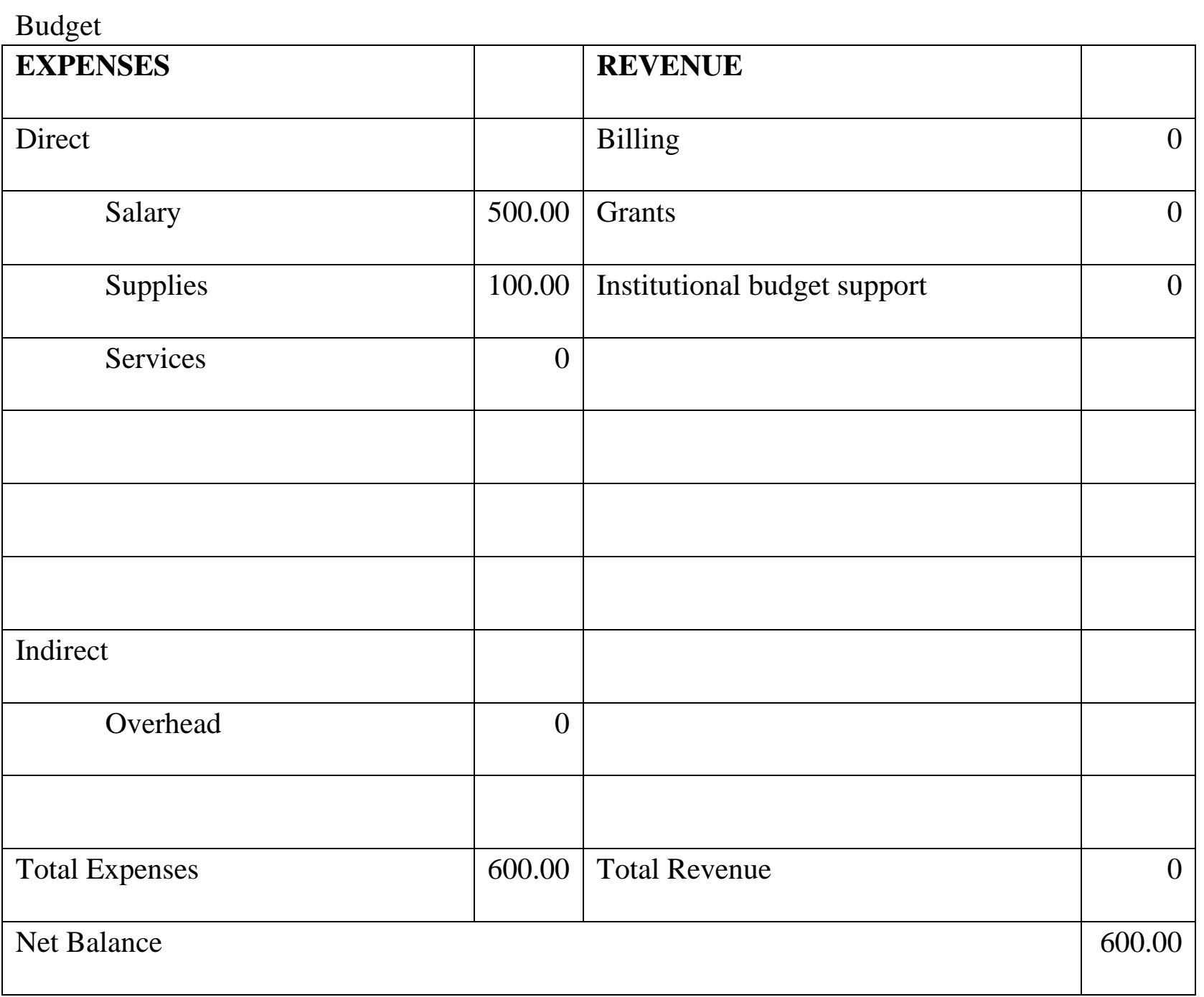




\section{Appendix B}

\section{Summary of Primary Research Evidence}

Summary of Primary Research Evidence

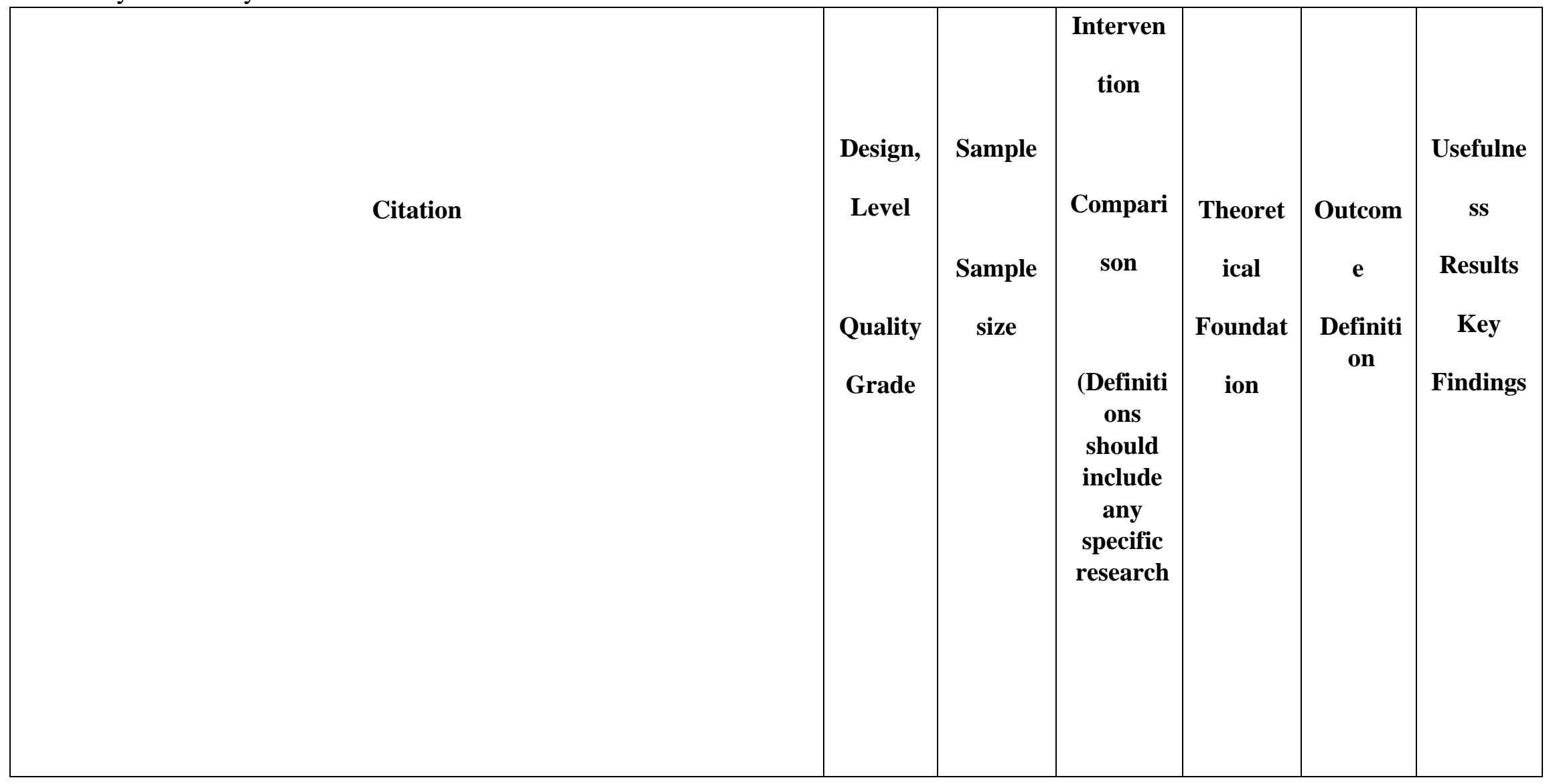




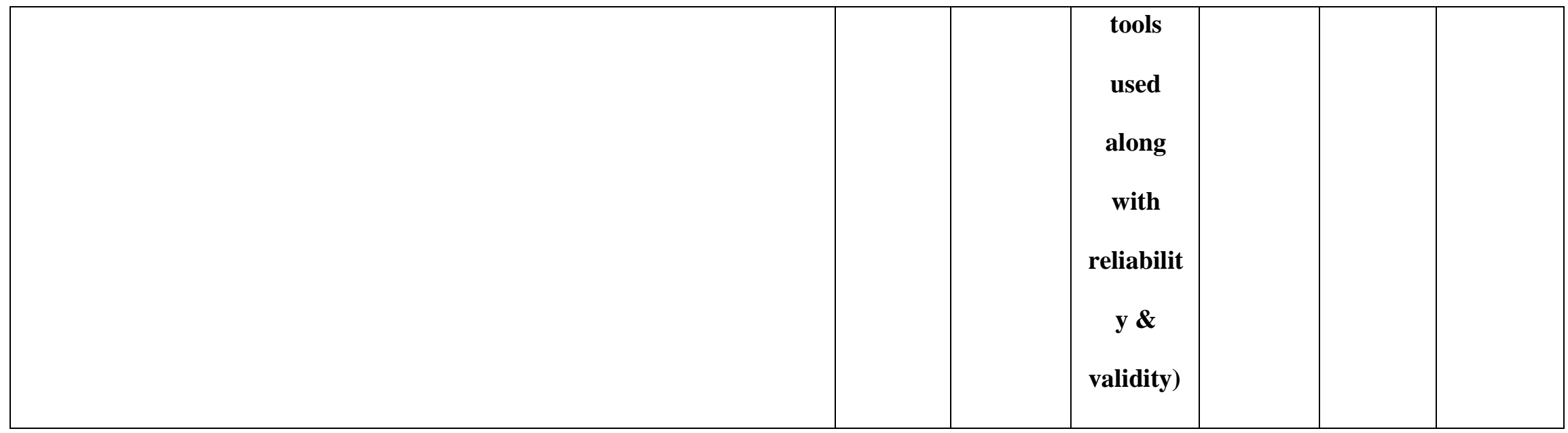




\begin{tabular}{|c|c|c|c|c|c|c|}
\hline $\begin{array}{l}\text { Janus, S., Reinders, G. H., van Manen, J. G., Zuidema, S. U., \& IJzerman, M. } \\
\text { J. (2017). Psychotropic drug-related fall incidents in nursing home residents } \\
\text { living in the eastern part of The Netherlands. Drugs in R\&D, 17(2), } \\
\text { 321-328. https://doi.org/10.1007/s40268-017-0181-0 }\end{array}$ & $\begin{array}{l}\text { Cohort } \\
\text { study, } \\
\text { Level II } \\
\text { Quality } \\
\text { Grade: } \\
\text { High }\end{array}$ & $\begin{array}{l}1415 \\
\text { patients }\end{array}$ & $\begin{array}{l}\text { Electroni } \\
\text { c } \\
\text { Medical } \\
\text { records } \\
\text { were used } \\
\text { to look at } \\
\text { patients } \\
\text { on } \\
\text { psychotro } \\
\text { pic } \\
\text { medicatio } \\
\text { ns to } \\
\text { determin } \\
\text { e if } \\
\text { patients } \\
\text { that were } \\
\text { not taking } \\
\text { psychotro } \\
\text { pic }\end{array}$ & $\begin{array}{l}\text { Cox } \\
\text { Proporti } \\
\text { onal } \\
\text { Hazards } \\
\text { Model } \\
\text { looks at } \\
\text { the } \\
\text { survival } \\
\text { time of a } \\
\text { patient } \\
\text { by an } \\
\text { illness or } \\
\text { injury. }\end{array}$ & $\begin{array}{c}\text { It was } \\
\text { determi } \\
\text { ned that } \\
\text { not all } \\
\text { psychotr } \\
\text { opics } \\
\text { harbore } \\
\text { d the } \\
\text { same } \\
\text { amount } \\
\text { of risk } \\
\text { for falls. } \\
\text { Individu } \\
\text { al drugs } \\
\text { caused } \\
\text { more } \\
\text { falls } \\
\text { than } \\
\text { others. }\end{array}$ & $\begin{array}{c}\text { Gives a } \\
\text { close } \\
\text { look at the } \\
\text { incidents } \\
\text { of falls in } \\
\text { older } \\
\text { patients } \\
\text { that are } \\
\text { taking } \\
\text { psychotro } \\
\text { pic } \\
\text { medicatio } \\
\text { ns }\end{array}$ \\
\hline & & & $\begin{array}{l}\text { medicatio } \\
\text { ns had } \\
\text { more } \\
\text { falls than } \\
\text { those that } \\
\text { did. }\end{array}$ & & & \\
\hline
\end{tabular}




\begin{tabular}{|c|c|c|c|c|c|c|}
\hline $\begin{array}{l}\text { Turner, K., Bjarnadottir, R., Jo, A., Repique, R. J. R., Thomas, J., Green, J. } \\
\text { F., \& Staggs, V. S. (2020). Patient falls and injuries in US psychiatric care: } \\
\text { Incidence and trends. Psychiatric Services, 71(9), 899-905. } \\
\text { https://doi.org/10.1176/appi.ps.202000004 }\end{array}$ & $\begin{array}{l}\text { Cohort } \\
\text { Study, } \\
\text { Level II } \\
\text { Quality } \\
\text { Grade: } \\
\text { High }\end{array}$ & $\begin{array}{l}1,159 \\
\text { psychiat } \\
\text { ric units } \\
\text { in } 720 \\
\text { hospitals }\end{array}$ & $\begin{array}{l}\text { Data was } \\
\text { collected } \\
\text { from the } \\
\text { National } \\
\text { Database } \\
\text { of } \\
\text { Nursing } \\
\text { Quality } \\
\text { Indicator } \\
\text { s } \\
\text { (NDNQI) } \\
\text { to } \\
\text { calculate } \\
\text { the } \\
\text { number } \\
\text { of total } \\
\text { falls, falls } \\
\text { slowed or } \\
\text { assisted } \\
\text { by the } \\
\text { staff, and } \\
\text { falls } \\
\text { leading to } \\
\text { injury in } \\
\text { psychiatri } \\
\text { c } \\
\text { patients. } \\
\text { There }\end{array}$ & $\begin{array}{l}\text { Imogene } \\
\text { King's } \\
\text { Theory of } \\
\text { Goal } \\
\text { Attainm } \\
\text { ent states } \\
\text { that the } \\
\text { nurse is } \\
\text { part of } \\
\text { the } \\
\text { patient's } \\
\text { environ } \\
\text { ment. In } \\
\text { this } \\
\text { study, it } \\
\text { was } \\
\text { proven } \\
\text { that } \\
\text { assisted } \\
\text { or slowed } \\
\text { falls by } \\
\text { the nurse } \\
\text { or staff } \\
\text { rendered } \\
\text { less } \\
\text { serious } \\
\text { injuries. }\end{array}$ & $\begin{array}{c}\text { Falls } \\
\text { remain a } \\
\text { significa } \\
\text { nt } \\
\text { problem } \\
\text { in } \\
\text { psychiat } \\
\text { ric units. } \\
\text { Geripsych } \\
\text { patients } \\
\text { have } \\
\text { more } \\
\text { falls with } \\
\text { injury } \\
\text { than do } \\
\text { adult } \\
\text { psych } \\
\text { patients. }\end{array}$ & $\begin{array}{l}\text { This study } \\
\text { articulate } \\
\text { s that the } \\
\text { number } \\
\text { of falls } \\
\text { among } \\
\text { psychiatri } \\
\text { c patients } \\
\text { is not } \\
\text { vastly } \\
\text { different } \\
\text { from } \\
\text { hospitaliz } \\
\text { ed } \\
\text { patients } \\
\text { without } \\
\text { psych } \\
\text { diagnoses } \\
\text { on } \\
\text { nonpsych } \\
\text { units. }\end{array}$ \\
\hline
\end{tabular}




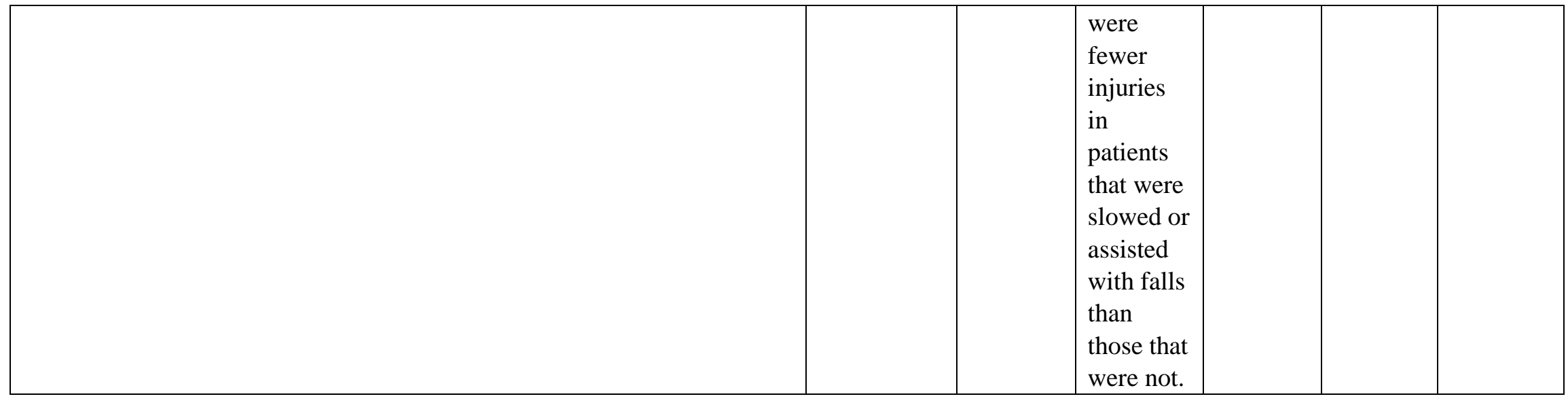




\begin{tabular}{|c|c|c|c|c|c|c|}
\hline $\begin{array}{l}\text { Wang, K. N., Bell, J. S., Gilmartin-Thomas, J. F. M., Tan, E. C. K., } \\
\text { Cooper, T., Robson, L., \& Ilomäki, J. (2021). Use of falls risk-increasing } \\
\text { drugs in residents at high and low falls risk in aged care services. Journal } \\
\text { of Applied Gerontology, 40(1), } 77-86 . \\
\text { https://doi.org/10.1177/0733464819888848 }\end{array}$ & $\begin{array}{l}\text { Seconda ry } \\
\text { crosssectiona } \\
1 \\
\text { analyses } \\
\text { Level II, } \\
\text { Quality } \\
\text { Grade: } \\
\text { High }\end{array}$ & $\begin{array}{l}383 \\
\text { patients }\end{array}$ & $\begin{array}{l}\text { The } \\
\text { modified } \\
\text { version } \\
\text { of } \\
\text { Delbaere' } \\
\text { s } \\
\text { algorithm } \\
\text { is a } \\
\text { flowchart } \\
\text { fall risk } \\
\text { assessme } \\
\text { nt that } \\
\text { categoriz } \\
\text { es both } \\
\text { ambulato } \\
\text { ry and } \\
\text { immobile } \\
\text { as a high } \\
\text { or low } \\
\text { fall risk. } \\
\text { Did } \\
\text { applying } \\
\text { a fall risk }\end{array}$ & $\begin{array}{l}\text { Sister } \\
\text { Callista } \\
\text { Roy's } \\
\text { Adaptati } \\
\text { on } \\
\text { Model. } \\
\text { First, } \\
\text { you } \\
\text { must } \\
\text { assess } \\
\text { the } \\
\text { mainten } \\
\text { ance of } \\
\text { the } \\
\text { physical } \\
\text { body. } \\
\text { Then the } \\
\text { nurse } \\
\text { must } \\
\text { assess } \\
\text { the } \\
\text { environ } \\
\text { ment to }\end{array}$ & $\begin{array}{c}\text { Reducti } \\
\text { on in } \\
\text { fall risk- } \\
\text { inducing } \\
\text { drugs } \\
\text { (FRID) } \\
\text { such as } \\
\text { psychot } \\
\text { opics } \\
\text { and } \\
\text { drugs } \\
\text { that } \\
\text { cause } \\
\text { orthosta } \\
\text { ic } \\
\text { hypoten } \\
\text { sion are } \\
\text { essentia } \\
\text { in } \\
\text { decreasi } \\
\text { ng falls. } \\
\text { Patients } \\
\text { on 2+ }\end{array}$ & $\begin{array}{l}\text { Looking } \\
\text { at how } \\
\text { fall risk } \\
\text { assessme } \\
\text { nts help } \\
\text { the red } \\
\text { flag a } \\
\text { patient at } \\
\text { risk and } \\
\text { function } \\
\text { as an aid } \\
\text { to } \\
\text { adapting } \\
\text { the } \\
\text { patient's } \\
\text { plan of } \\
\text { care. }\end{array}$ \\
\hline
\end{tabular}




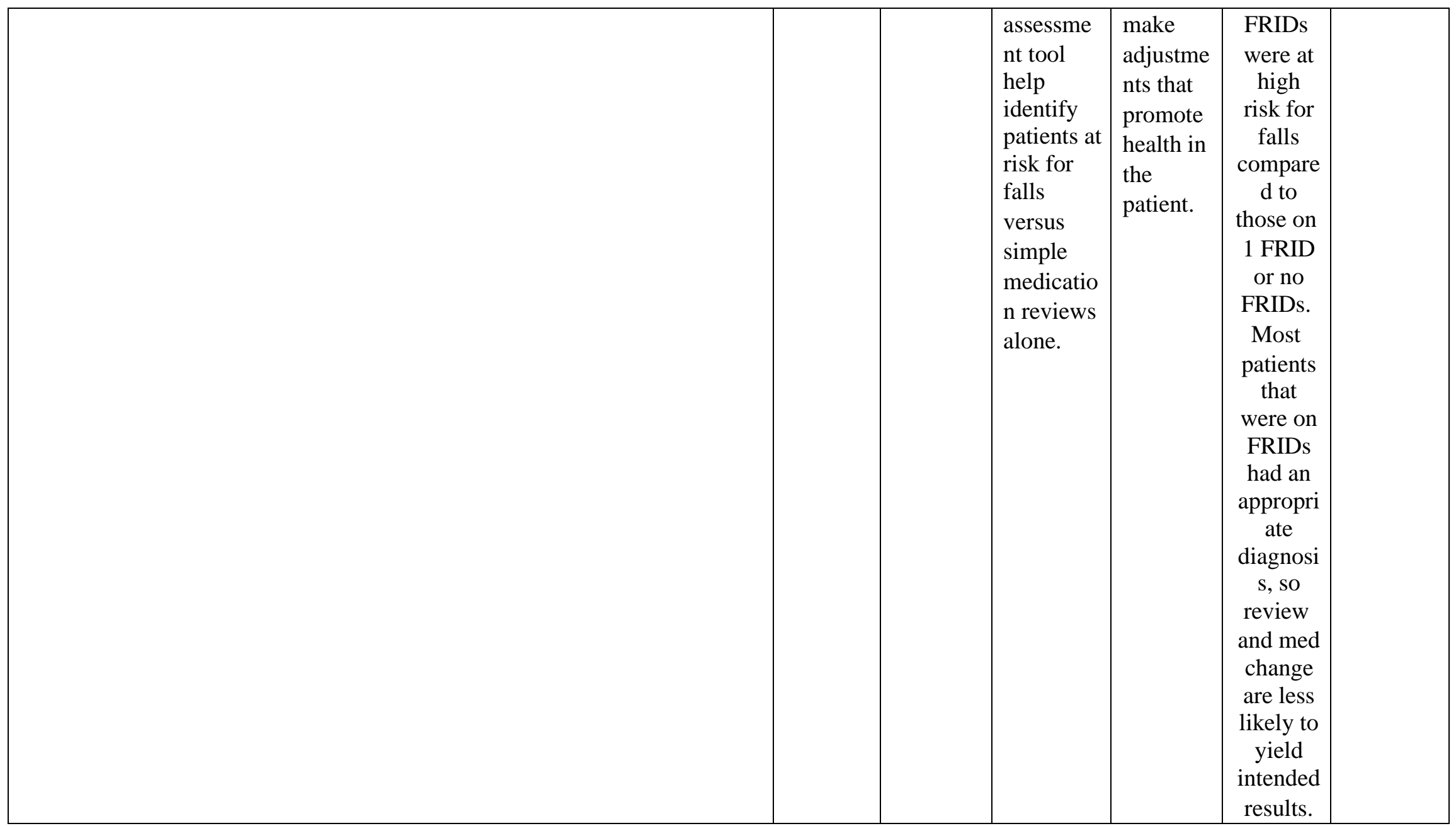


Morici, V., Terzoni, S., Ferrara, P., \& Destrebecq, A. (2021). Development and validation of a new tool for assessing the risk of falls in acute

psychiatric settings. International Journal of Emergency Mental Health and

Human Resilience, 18(2), 742-747.

https://www.omicsonline.org/openaccess/development-and-validation-of-anew-tool-for-assessing-risk-offallsin-acute-psychiatric-settings-1522-4821-

1000330.pdf

\begin{tabular}{|c|c|c|c|c|c|}
\hline \begin{tabular}{|l} 
Literatu \\
re \\
Review, \\
Level II, \\
Quality \\
Grade:
\end{tabular} & $\begin{array}{l}123 \\
\text { patients } \\
\text { in three } \\
\text { units }\end{array}$ & $\begin{array}{l}\text { The } \\
\text { impleme } \\
\text { ntation of } \\
\text { a tool } \\
\text { that is all } \\
\text { the items }\end{array}$ & $\begin{array}{l}\text { Betty } \\
\text { Neuman } \\
\text { 's } \\
\text { Systems } \\
\text { Model is } \\
\text { the }\end{array}$ & $\begin{array}{c}\text { Not all } \\
\text { highrisk } \\
\text { patients } \\
\text { sustaine } \\
\text { d a fall. }\end{array}$ & $\begin{array}{l}\text { This looks } \\
\text { at the } \\
\text { Edmonso } \\
\mathrm{n} \text { tool in } \\
\text { correlatio }\end{array}$ \\
\hline
\end{tabular}




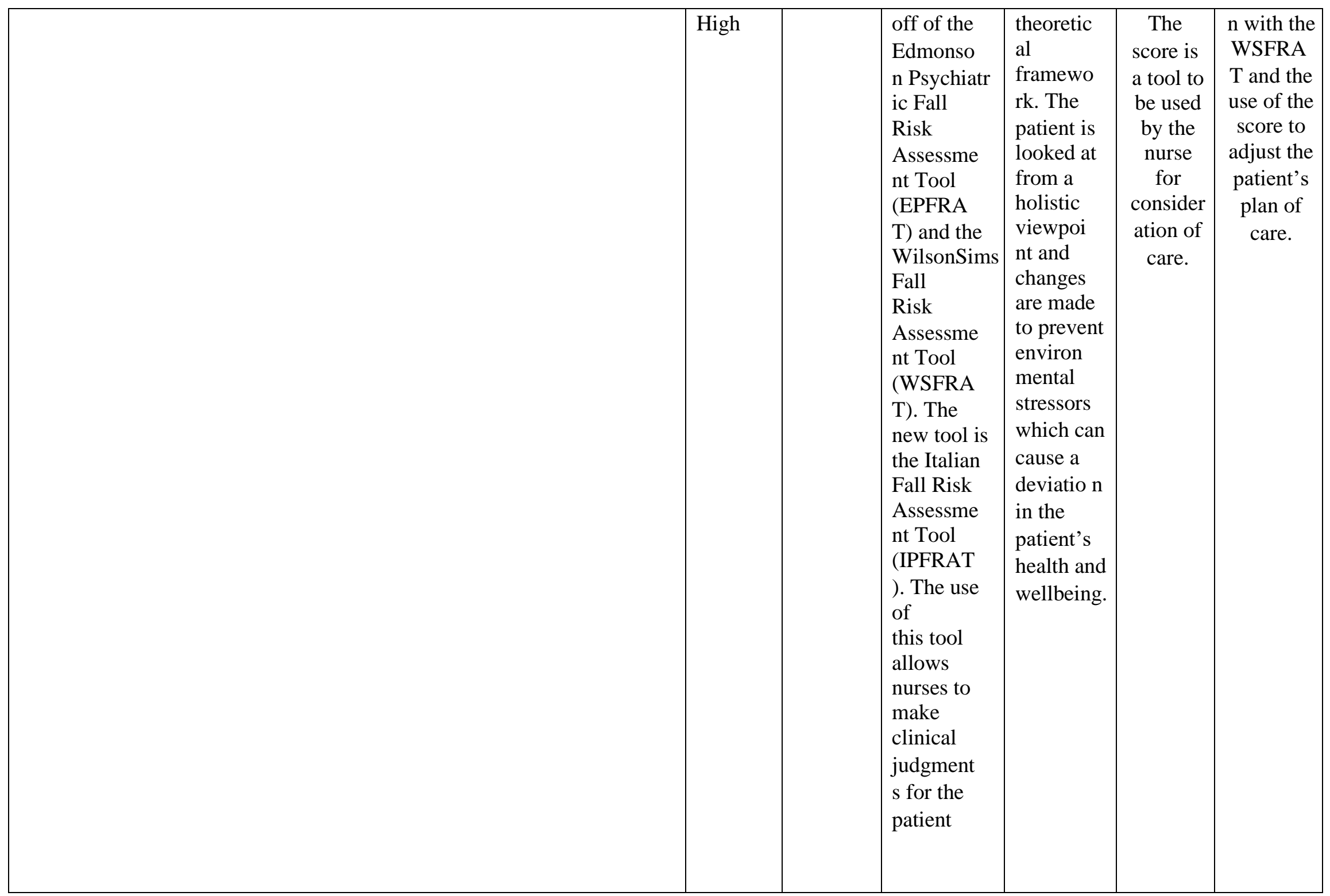




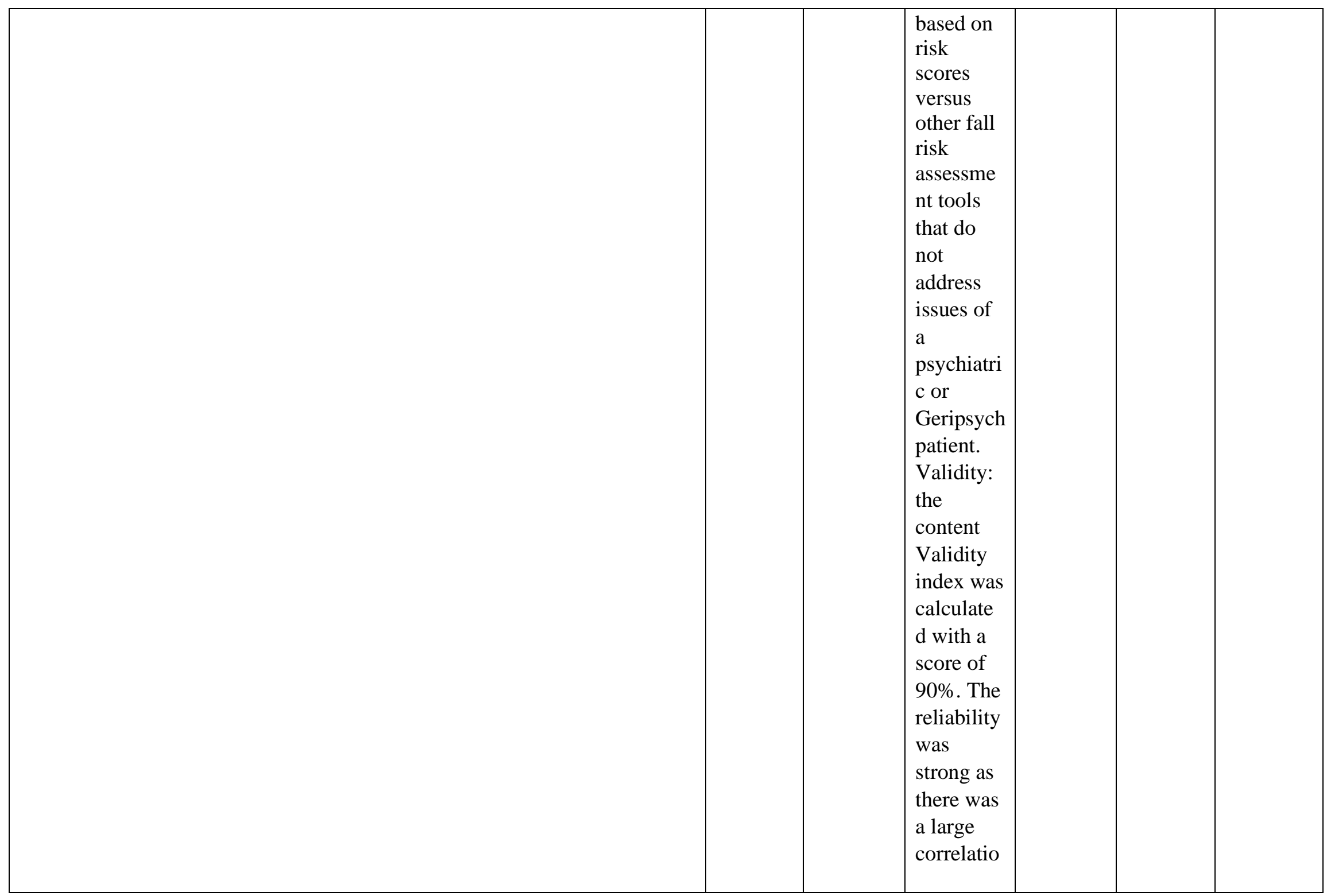




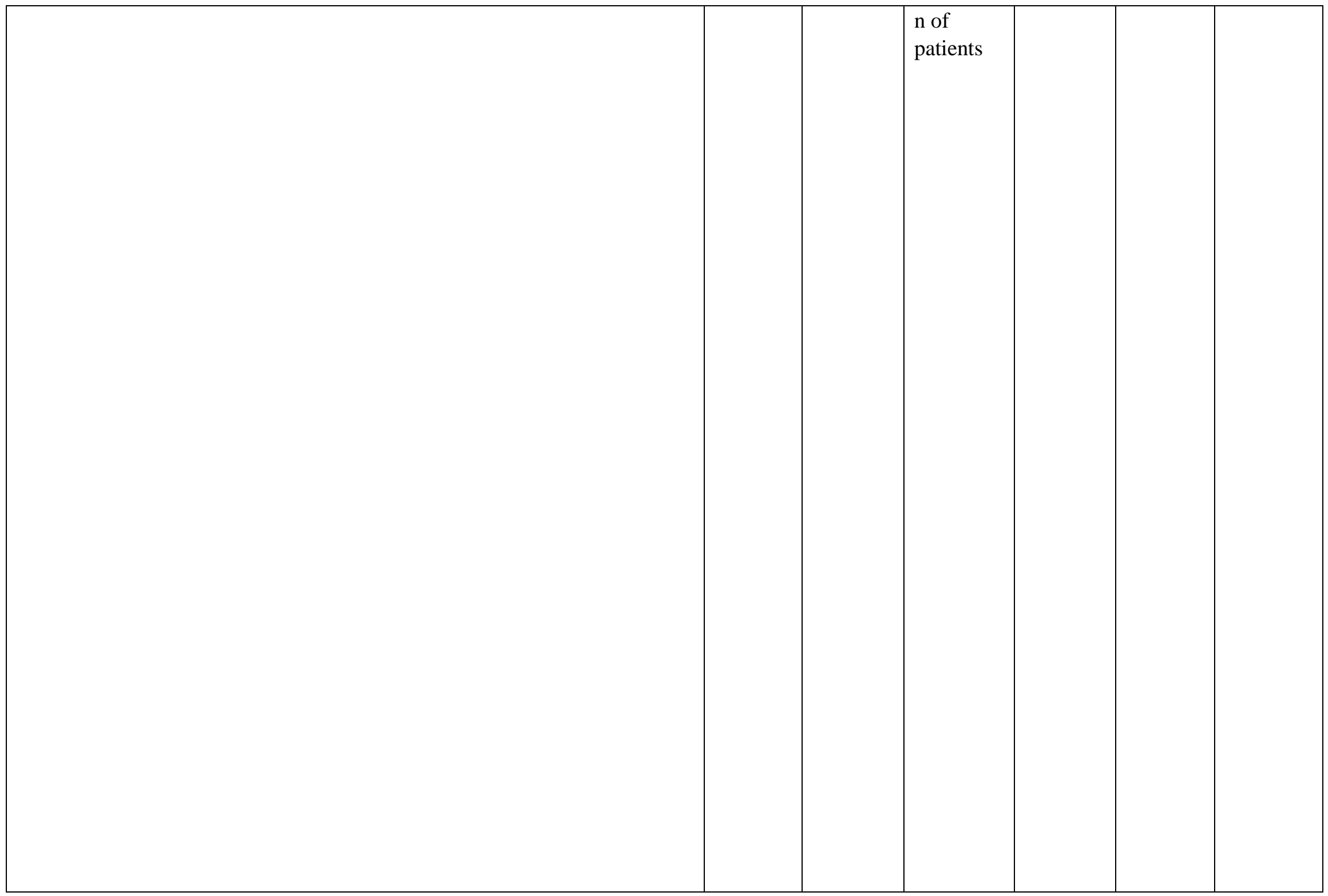




\begin{tabular}{|c|c|c|c|c|c|c|}
\hline & & & $\begin{array}{l}\text { on } \\
\text { psychotro } \\
\text { pics to } \\
\text { patients } \\
\text { that fell. } \\
\text { Pearson } \\
\text { r }=0.93\end{array}$ & & & \\
\hline $\begin{array}{l}\text { Bosse, J., \& LaPoint, C. (n.d.) Sensitivity and specificity of the Edmonson } \\
\text { Psychiatric Fall Risk Assessment Tool in an adult inpatient psychiatric unit. } \\
\text { UMASS Amherst College of Nursing. Retrieved month date, year, from } \\
\text { https://sigma.nursingrepository.org/bitstream/handle/10755/603255/1_Bosse } \\
\text { _J_p70991_2.pdf?sequence=1\&isAllowed=y }\end{array}$ & $\begin{array}{l}\text { Retrosp } \\
\text { ective } \\
\text { Review, } \\
\text { Level II, } \\
\text { Quality } \\
\text { Grade: } \\
\text { Good }\end{array}$ & $\begin{array}{l}161 \\
\text { complet } \\
\text { ed } \\
\text { assessm } \\
\text { ents }\end{array}$ & $\begin{array}{l}\text { A } \\
\text { Sensitivit } \\
\text { y and } \\
\text { Specificit } \\
\text { y was } \\
\text { complete } \\
\text { d, The } \\
\text { EPFRAT } \\
\text { was 80\% } \\
\text { more } \\
\text { Sensitive } \\
\text { and 96\% } \\
\text { more } \\
\text { specific } \\
\text { than } \\
\text { Johns } \\
\text { Hopkins } \\
\text { at } \\
\text { predictin } \\
\text { g falls. }\end{array}$ & $\begin{array}{l}\text { Dorothy } \\
\text { Johns Behavio } \\
\text { ral } \\
\text { Systems } \\
\text { Modelpromote } \\
\text { s effective } \\
\text { behavior } \\
\text { al functioni ng } \\
\text { to prevent } \\
\text { injury or } \\
\text { illness }\end{array}$ & $\begin{array}{c}\text { The RN } \\
\text { percepti } \\
\text { on of } \\
\text { usability } \\
\text { was } \\
83.3 \% \\
\text { for } \\
\text { EPFRA } \\
\text { T and } \\
100 \% \\
\text { for } \\
\text { Johns } \\
\text { Hopkins } \\
\text { Fall } \\
\text { Risk } \\
\text { Assessm } \\
\text { ent. }\end{array}$ & $\begin{array}{c}\text { This } \\
\text { study } \\
\text { was to } \\
\text { look at } \\
\text { the RN } \\
\text { usability } \\
\text { of the } \\
\text { EPFRAT } \\
\text { vs the } \\
\text { Johns } \\
\text { Hopkins } \\
\text { Fall } \\
\text { Assessme } \\
\text { nt tool. }\end{array}$ \\
\hline
\end{tabular}




\begin{tabular}{|c|c|c|c|c|c|c|}
\hline $\begin{array}{l}\text { Mathew, L., Steigman, D., Driscoll, D., Moran-Peters, J., Fischer, I. M., } \\
\text { Cordle, P., \& Eckardt, S. (2020). Making fall risk assessment clinically } \\
\text { relevant in an adult psychiatric setting. Journal of Psychosocial Nursing \& } \\
\text { Mental Health Services, 58(2), 21-26. } \\
\text { https://doi.org/10.3928/02793695-20191106-01 }\end{array}$ & $\begin{array}{l}\text { Nonexperim } \\
\text { ental Study } \\
\text { Level } \\
\text { III Quality } \\
\text { Grade: } \\
\text { Good }\end{array}$ & $\begin{array}{l}216 \\
\text { patients } \\
\text { where } \\
\text { EPFRA } \\
\text { T was } \\
\text { used } \\
\text { and } \\
\text { Twenty- } \\
\text { five } \\
\text { complet } \\
\text { ed nurse } \\
\text { question } \\
\text { naires } \\
\text { On ease } \\
\text { of use }\end{array}$ & $\begin{array}{l}\text { Chronbac } \\
\text { h's alpha } \\
\text { was } \\
\text { utilized } \\
\text { to check } \\
\text { the } \\
\text { reliability } \\
\text { of this } \\
\text { assessme } \\
\text { nt with } \\
\text { an alpha } \\
\text { score of } \\
92 \% \\
80 \% \text { of } \\
\text { the } \\
\text { nurses } \\
\text { graded } \\
\text { the test as } \\
\text { easy to } \\
\text { use and } \\
87.5 \% \\
\text { graded } \\
\text { the } \\
\text { EPFRAT } \\
\text { as } \\
\text { completel } \\
\text { y } \\
\text { relevant } \\
\text { giving it } \\
\text { a good } \\
\text { rating. }\end{array}$ & $\begin{array}{l}\text { Kurt Lewin's } \\
\text { Change } \\
\text { Model- } \\
\text { Recogni } \\
\text { zing the need } \\
\text { for change, } \\
\text { motivati ng } \\
\text { change, then } \\
\text { solidifyi ng } \\
\text { change }\end{array}$ & $\begin{array}{c}\text { The RN } \\
\text { percepti } \\
\text { on of } \\
\text { the } \\
\text { EPFRA } \\
\text { T } \\
\text { assessm } \\
\text { ent too } \\
\text { was that } \\
\text { it was } \\
\text { more } \\
\text { user- } \\
\text { friendly } \\
\text { and } \\
\text { more } \\
\text { relevant } \\
\text { to } \\
\text { psychiat } \\
\text { ric } \\
\text { patients } \\
\text { than the } \\
\text { Morse } \\
\text { Fall } \\
\text { Scale. }\end{array}$ & $\begin{array}{c}\text { This } \\
\text { study } \\
\text { was to } \\
\text { look at } \\
\text { the } \\
\text { perceptio } \\
\text { n of the } \\
\text { use of the } \\
\text { EPFRAT } \\
\text { versus } \\
\text { the } \\
\text { Morse } \\
\text { fall scale } \\
\text { before } \\
\text { and after } \\
\text { the } \\
\text { impleme } \\
\text { ntation of } \\
\text { the tool } \\
\text { and to } \\
\text { look to } \\
\text { see if the } \\
\text { tool was } \\
\text { effective } \\
\text { in } \\
\text { decreasin } \\
\text { g falls. }\end{array}$ \\
\hline
\end{tabular}


Appendix C

Figure 1

\section{SWOT}

\section{Assessment}
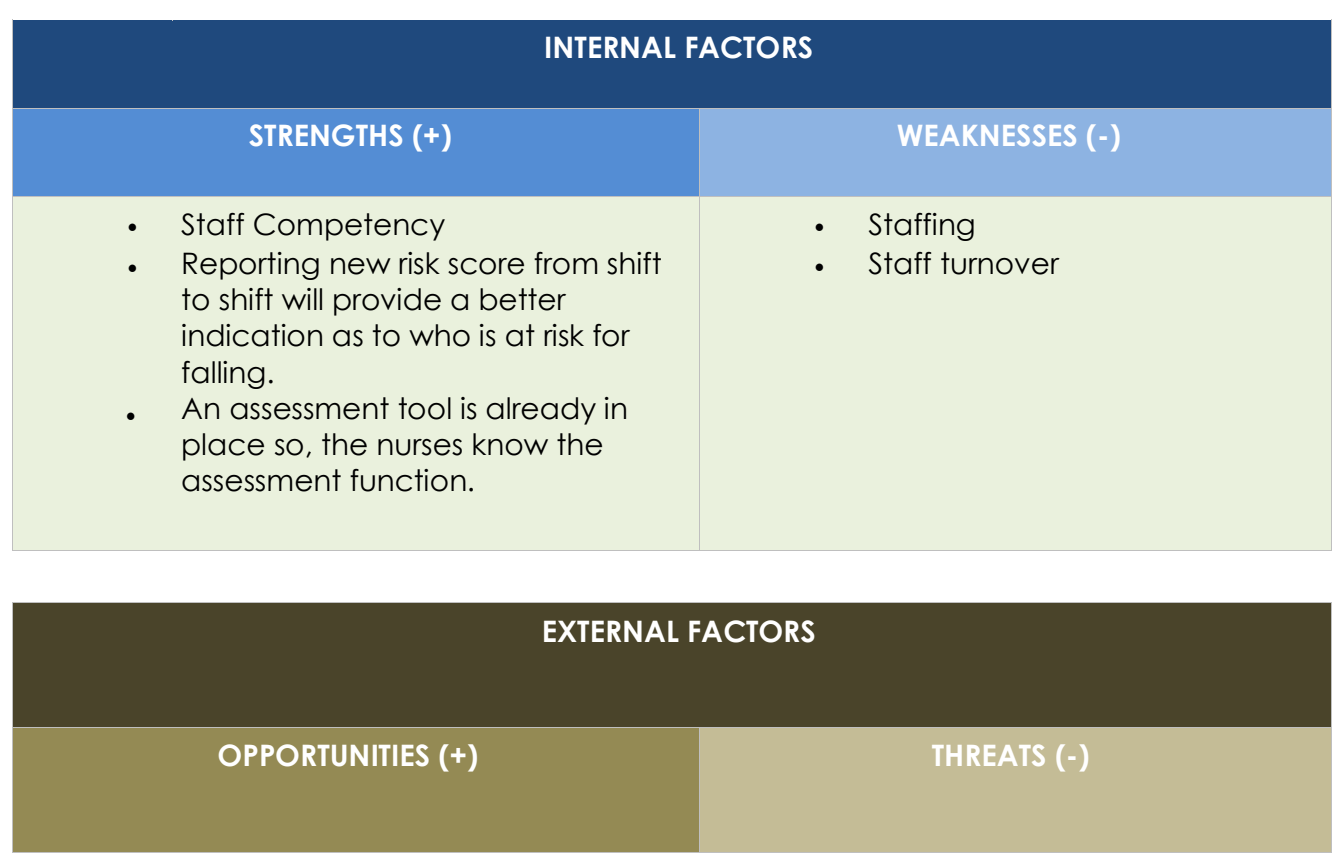


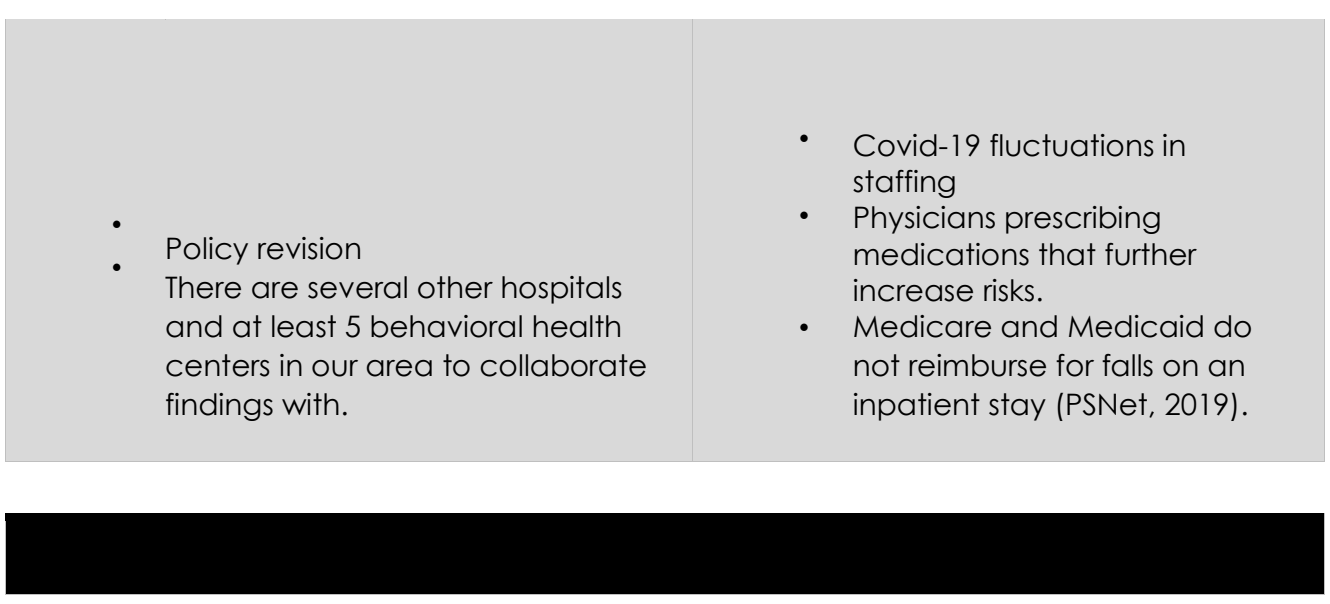

\section{Appendix D}


PRISMA 2009 Flow Diagram

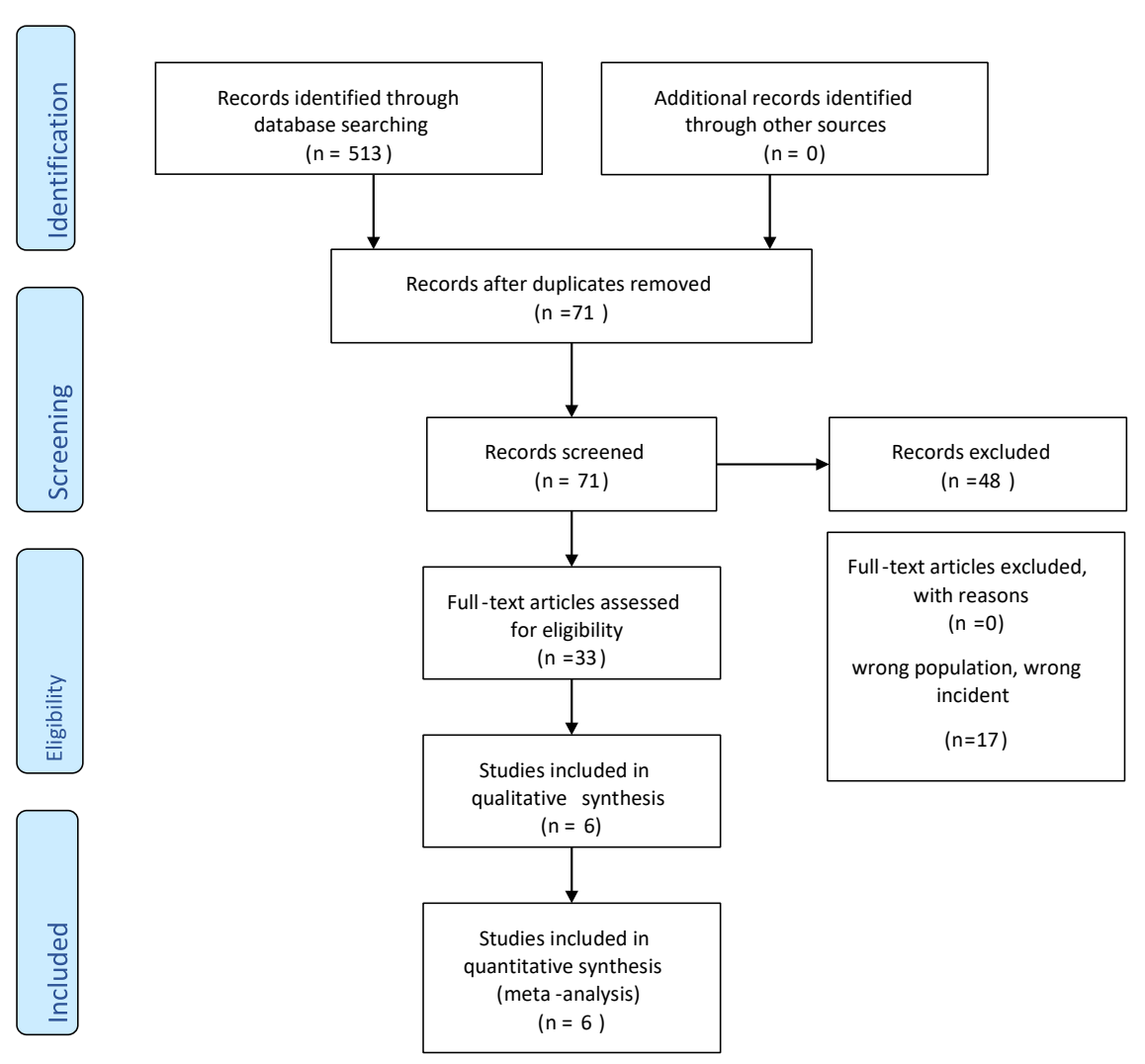

University of North Carolina Library of Health Sciences. (2021).Creating a PRISMA flow diagram. https://guides.lib.unc.edu/prisma Appendix E

Project Schedule

\begin{tabular}{|l|l|l|l|}
\hline & NUR7801 NUR7803 & NUR7802 \\
\hline
\end{tabular}




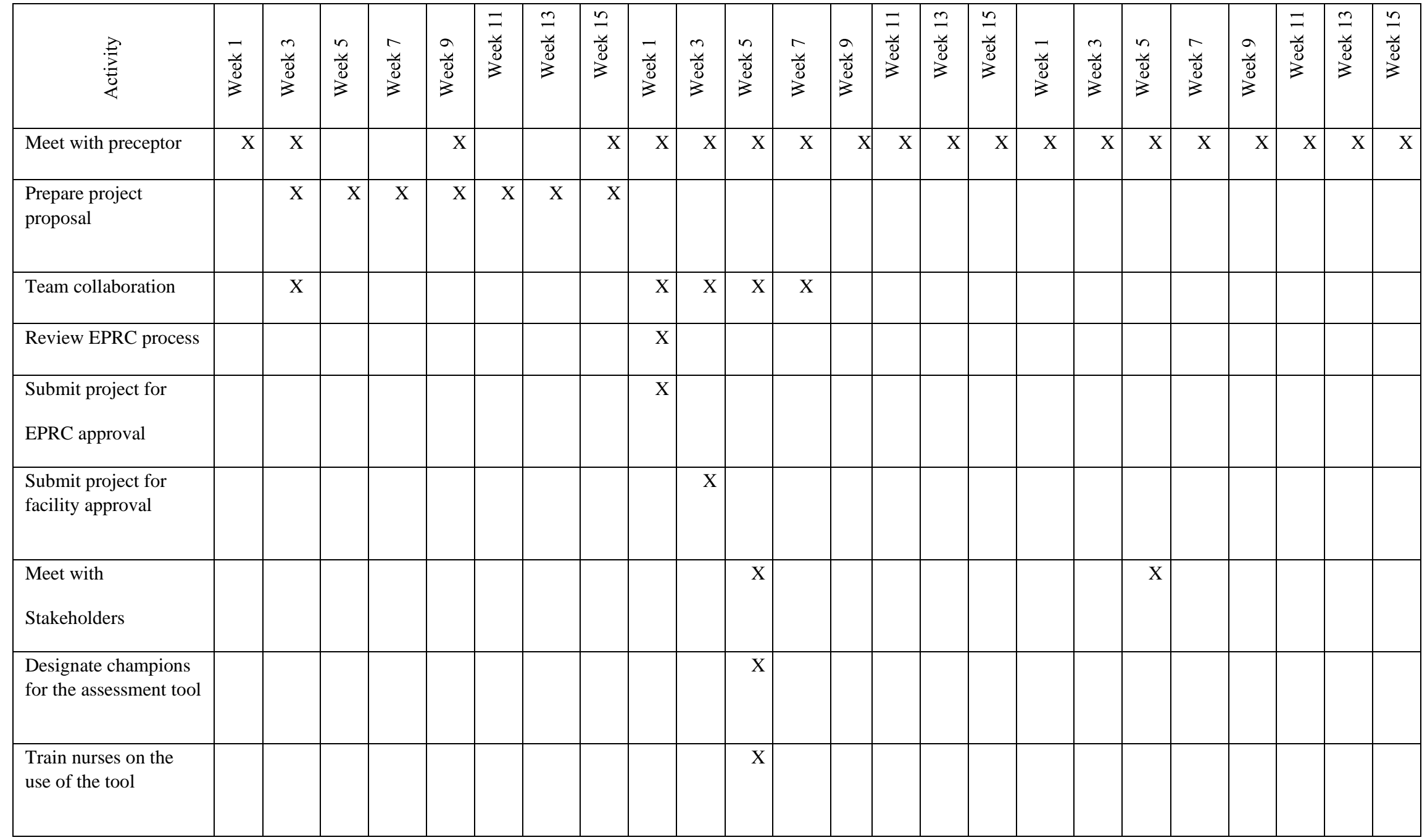

\begin{tabular}{|c|c|c|c|c|c|c|c|c|c|c|c|c|c|c|c|c|c|c|c|c|c|c|c|c|}
\hline & \multicolumn{8}{|c|}{ NUR7801 } & \multicolumn{8}{|c|}{ NUR7802 } & \multicolumn{8}{|c|}{ NUR7803 } \\
\hline 胥 & $\begin{array}{l}\vec{y} \\
\overrightarrow{0} \\
\overrightarrow{3}\end{array}$ & $\begin{array}{l}m \\
\frac{n}{d} \\
\vec{j}\end{array}$ & $\begin{array}{l}n \\
y \\
y \\
z\end{array}$ & $\begin{array}{l}\bar{y} \\
\bar{y} \\
\bar{z}\end{array}$ & $\begin{array}{l}\hat{y} \\
\bar{j} \\
\overrightarrow{3}\end{array}$ & 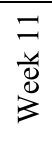 & $\begin{array}{l}\frac{m}{y} \\
\frac{u}{0} \\
3\end{array}$ & $\begin{array}{l}\frac{n}{n} \\
\frac{u}{8} \\
3\end{array}$ & $\begin{array}{l}\overrightarrow{\breve{s}} \\
\vec{d}\end{array}$ & $\begin{array}{l}m \\
\frac{m}{0} \\
\vec{j}\end{array}$ & $\begin{array}{l}n \\
\ddot{0} \\
3 \\
3\end{array}$ & $\begin{array}{l}\bar{y} \\
\bar{y} \\
\bar{z}\end{array}$ & $\begin{array}{l}a \hat{y} \\
\ddot{J} \\
3\end{array}$ & $\begin{array}{l}= \\
\text { J } \\
3\end{array}$ & $\begin{array}{l}m \\
\frac{m}{8} \\
3 \\
3\end{array}$ & $\begin{array}{l}n \\
\frac{n}{8} \\
3\end{array}$ & $\begin{array}{l}\vec{y} \\
\frac{u}{3} \\
3\end{array}$ & $\begin{array}{l}m \\
\frac{n}{3} \\
3\end{array}$ & $\begin{array}{l}n \\
\tilde{y} \\
\tilde{z} \\
z\end{array}$ & $\begin{array}{l}\bar{y} \\
\bar{u} \\
\bar{z}\end{array}$ & $\begin{array}{l}\frac{a}{u} \\
\frac{0}{3}\end{array}$ & $\begin{array}{l}= \\
\text { J } \\
3\end{array}$ & $\begin{array}{l}m \\
\frac{m}{8} \\
3\end{array}$ & $\begin{array}{l}\frac{n}{4} \\
\frac{u}{\pi} \\
3\end{array}$ \\
\hline $\begin{array}{l}\text { Collect } \\
\text { preimplementation data }\end{array}$ & & & & & & & & & & & $\mathrm{X}$ & & & & & & & & & & & & & \\
\hline
\end{tabular}




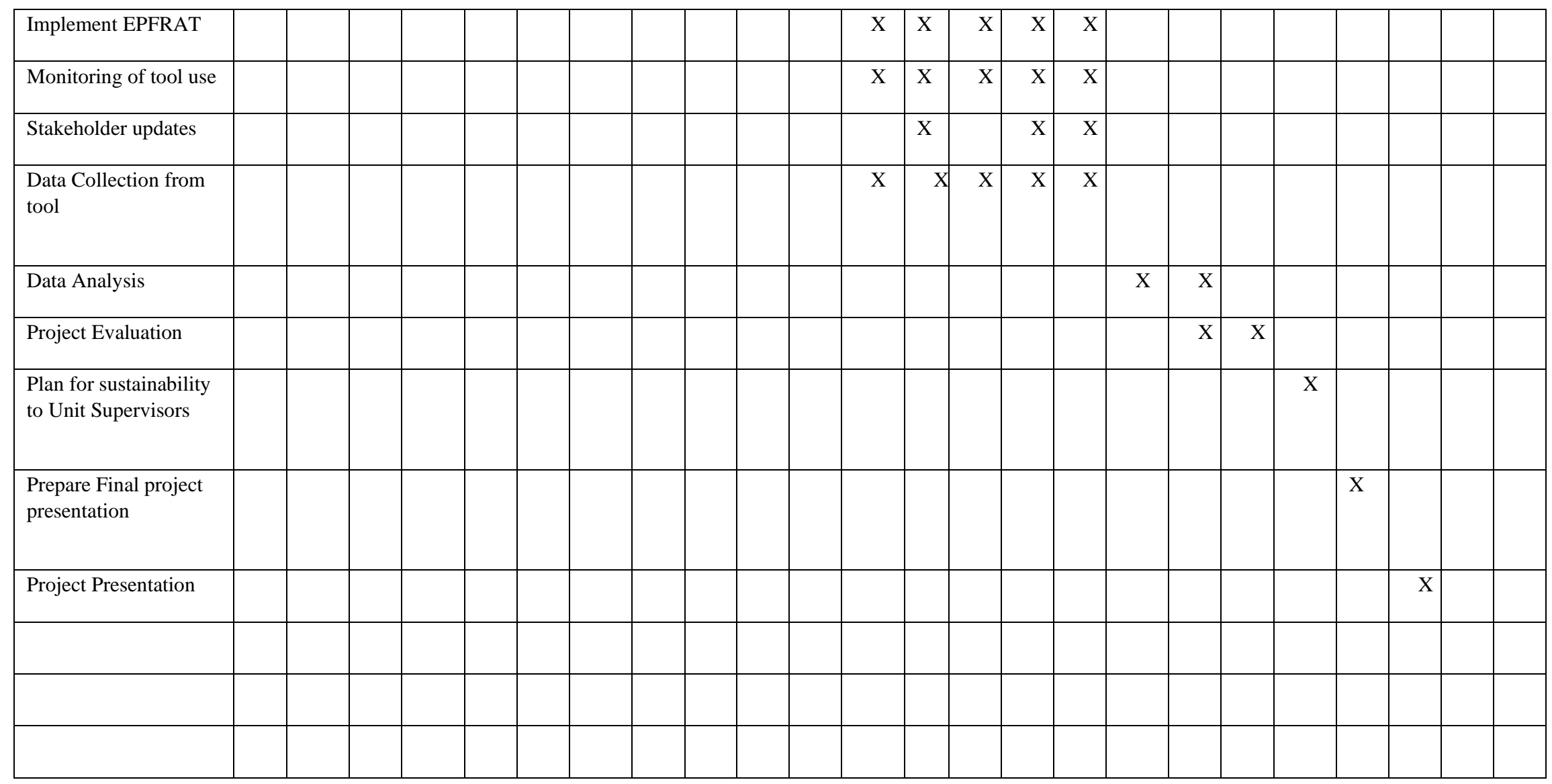

\begin{tabular}{|c|c|c|c|c|c|c|c|c|c|c|c|c|c|c|c|c|c|c|c|c|c|c|c|c|}
\hline & \multicolumn{8}{|c|}{ NUR7801 } & \multicolumn{8}{|c|}{ NUR7802 } & \multicolumn{8}{|c|}{ NUR7803 } \\
\hline 总 & $\begin{array}{l}\vec{y} \\
\frac{0}{3} \\
3\end{array}$ & $\begin{array}{l}m \\
\ddot{y} \\
0 \\
3\end{array}$ & $\begin{array}{l}n \\
\frac{y}{0} \\
3 \\
3\end{array}$ & $\frac{r}{y}$ & $\begin{array}{l}a \\
\frac{y}{u} \\
z\end{array}$ & $\begin{array}{l}= \\
y \\
y \\
3\end{array}$ & $\begin{array}{l}m \\
\frac{\pi}{8} \\
3 \\
3\end{array}$ & $\begin{array}{l}n \\
\frac{n}{d} \\
\frac{d}{3}\end{array}$ & $\begin{array}{l}\bar{y} \\
\frac{\pi}{3} \\
3\end{array}$ & $\begin{array}{l}n \\
\text { ñ } \\
3 \\
3\end{array}$ & $\begin{array}{l}n \\
\frac{n}{8} \\
3 \\
3\end{array}$ & $\frac{\bar{y}}{3}$ & $\begin{array}{l}a \\
y \\
\frac{u}{d} \\
z\end{array}$ & $\begin{array}{l}\Xi \\
\bar{y} \\
\overline{0} \\
3\end{array}$ & $\begin{array}{l}n \\
\frac{y}{d} \\
\frac{d}{3}\end{array}$ & $\begin{array}{l}n \\
\frac{n}{8} \\
3\end{array}$ & $\frac{\bar{y}}{\vec{d}}$ & $\begin{array}{l}m \\
\ddot{d} \\
\dot{z}\end{array}$ & $\begin{array}{l}n \\
y \\
\ddot{d} \\
3\end{array}$ & $\begin{array}{l}\frac{\pi}{0} \\
\frac{\pi}{3}\end{array}$ & $\begin{array}{l}a \\
\frac{u}{u} \\
z\end{array}$ & $\begin{array}{l}= \\
y \\
\ddot{d} \\
3 \\
3\end{array}$ & $\begin{array}{l}m \\
\bar{y} \\
\dot{0} \\
3\end{array}$ & $\begin{array}{l}n \\
\frac{n}{d} \\
3\end{array}$ \\
\hline & & & & & & & & & & & & & & & & & & & & & & & & \\
\hline
\end{tabular}




\section{Appendix F}

\section{Edmonson Psychiatric Fall Risk Assessment (C)}

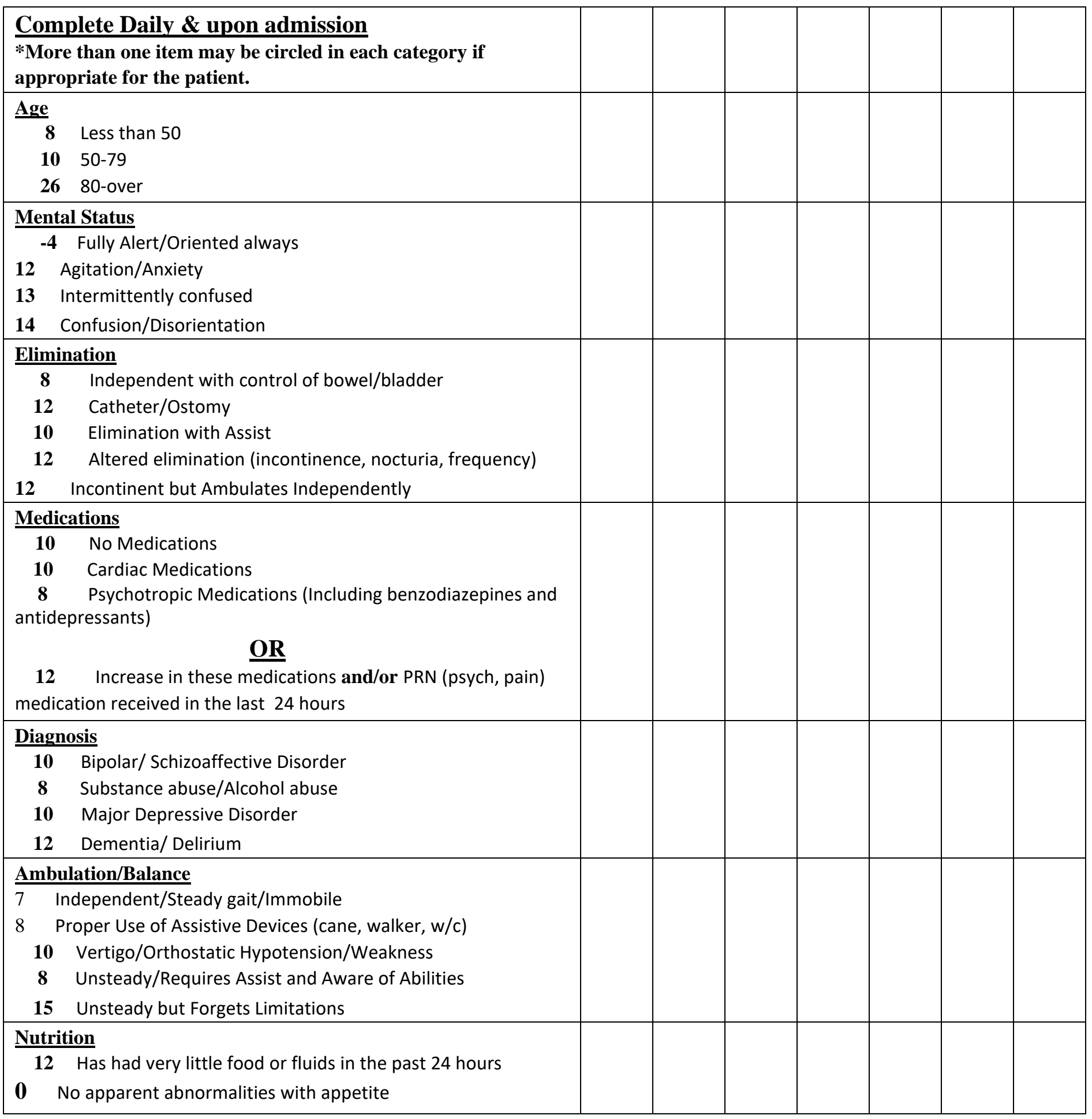




\begin{tabular}{|c|l|l|l|l|l|l|}
\hline Sleep Disturbance & & & & & & \\
\hline $\mathbf{8}$ No Sleep Disturbance & & & \\
$\mathbf{1 2}$ Report of Sleep Disturbance by patient, family, or staff & & & & & & \\
\hline History of Falls & & & & \\
\hline $\mathbf{8}$ No History of Falls & & & \\
\hline $\mathbf{1 4}$ History of Falls in the last 3 months & & & \\
\hline
\end{tabular}

$* *$ FALL RISK $=$ SCORE OF 90 OR GREATER **

\section{Definition Key for Risk Factors: Edmonson Fall Risk Assessment Tool}

Mental Status:

The patient may score for Agitation/ Anxiety and the other categories including Fully alert, intermittently confused, or Confused/disorientated. Elimination:

Elimination with assistance is defined as follows:

20 Patient calls for assistance with toileting regularly.

Diagnosis:

Use the physician's diagnosis. Some patients may have more than one diagnosis. The patient may score for each diagnosis, for example, Major Depressive Disorder and Alcohol Abuse.

Ambulation/ Balance:

The patient may score in more than one category, for example, Independent and

Orthostatic hypotension.

Nutrition:

Use the Nurses Notes (24-hour summaries) or Admission Profile to obtain this information.

A patient can be given a score of 12 based on any of the following:

20 Caregiver or patient report decreased appetite and intake of food and fluids over the last 24 hours.

2๑ Documentation of patient meal/ supplement intake of less than $50 \%$ over the last 24 hours. 
20 Documentation of "poor fluid intake" within the last 24 hours by nurses and/or nursing technicians.

20 Physical assessment reveals signs of dehydration or poor fluid intake (for example poor skin turgor, dry mucous membranes, abnormal labs). Sleep Disturbance:

Use the Nurses Notes (24-hour summaries) or Admission Profile to obtain this information.

A patient can be given a score of 12 for sleep disturbance for any of the following:

20 Patient, family, or caregiver report sleep disturbance (for example "not sleeping", "awake half the night").

20 Documentation of 4hours or less of consecutive sleep the night before the assessment. History of Falls:

Use the Nurses Notes (24-hour summaries) or Admission Profile to obtain this information.

\section{Medications}

[List includes, but is not limited to medication categories related to fall risk]

\begin{tabular}{|c|c|c|c|}
\hline \multicolumn{2}{|c|}{ Psychotropics } & \multicolumn{2}{|c|}{ Antidepressants } \\
\hline Haldol & Thorazine & Zoloft & Prozac \\
\hline Risperdal & Navane & Celexa & Amitriptyline \\
\hline \multicolumn{2}{|c|}{ Zyprexa Prolixin } & Lexapro & Nortriptyline \\
\hline \multicolumn{2}{|c|}{ Geodon Loxapine } & Wellbutrin & Trazadone \\
\hline \multicolumn{2}{|c|}{ Clozaril Perphenazine } & Effexor (XR) & Imipramine \\
\hline \multicolumn{2}{|c|}{ Chlorprothioxene } & Paxil & Doxepin \\
\hline \multicolumn{2}{|l|}{ Seroquel } & Amoxapine & Luvox \\
\hline \multirow{4}{*}{\multicolumn{2}{|c|}{ Mellaril }} & Clomipramine & Ascendin \\
\hline & & Desipramine & Protriptyline \\
\hline & & Trimipramine & \\
\hline & & & $\begin{array}{l}\text { *Include MAOIs at nurses' } \\
\text { discretion. No current research } \\
\text { findings to support related falls. }\end{array}$ \\
\hline \multicolumn{4}{|c|}{ Benzodiazepines } \\
\hline \multicolumn{4}{|c|}{ Lorazepam (Ativan) } \\
\hline \multicolumn{4}{|c|}{ Clonazepam (Klonopin) } \\
\hline \multicolumn{4}{|c|}{ Diazepam (Valium) } \\
\hline \multicolumn{4}{|c|}{ Librium (Chlordiazepoxide) } \\
\hline \multicolumn{4}{|c|}{ Alprazolam (Xanax) } \\
\hline
\end{tabular}


Flurazepam

Midazolam

Oxazepam

Temazepam (Restoril)

Clorazepate

\section{$\underline{\text { Cardiac Medications }}$}

\section{Beta-Blockers}

Atenolol

Esmolol hydrochloride

Labetalol

Metoprolol

Nadolol

Pindolol

Propranolol

Sotalol

Timolol

\section{Antiarrhythmics}

Amiodarone hydrochloride

tosylate

Digoxin

Disopyramide phosphate

Encainede

Flecainide acetate

Lidocaine hydrochloride

Procainamide hydrochloride

Quinidine bisulfate

Tocainide hydrochloride

\section{Calcium Channel Blockers}

Amlodipine

Diltiazem

Isradipine

Nicardipine hydrochloride

Nifedipine

Verapamil

Alpha-adrenergic blockers

Doxazosin mesylate

Prazosin hydrochloride

Terazosin

ACE Inhibitors

Captopril Bretylium

Enalapril

Lisinopril

Quinapril hydrochloride

Benazepril

\section{Vasodilators}

Clonidine hydrochloride

Hydralazine hydrochloride

Isosorbide dinitrate

\section{Appendix G}

Morse Fall Scale 


\begin{tabular}{|c|c|c|}
\hline 1. History of falling & $\begin{array}{l}\text { No } \\
\text { Yes }\end{array}$ & $\begin{array}{r}0 \\
25\end{array}$ \\
\hline 2. Secondary diagnosis & $\begin{array}{l}\text { No } \\
\text { Yes }\end{array}$ & $\begin{array}{r}0 \\
15\end{array}$ \\
\hline $\begin{array}{l}\text { 3. Ambulatory aid } \\
\text { None/bed rest/nurse assist } \\
\text { Crutches/cane/walker } \\
\text { Furniture }\end{array}$ & & $\begin{array}{r}0 \\
15 \\
30\end{array}$ \\
\hline 4. IV or IV Access & $\begin{array}{l}\text { No } \\
\text { Yes }\end{array}$ & $\begin{array}{r}0 \\
20\end{array}$ \\
\hline $\begin{array}{l}\text { 5. Gait } \\
\text { Normal/bed rest/wheelchair } \\
\text { Weak } \\
\text { Impaired }\end{array}$ & & $\begin{array}{r}0 \\
10 \\
20\end{array}$ \\
\hline $\begin{array}{l}\text { 6. Mental status } \\
\text { Oriented to own ability } \\
\text { Overestimates or forgets limitations }\end{array}$ & & $\begin{array}{r}0 \\
15\end{array}$ \\
\hline
\end{tabular}

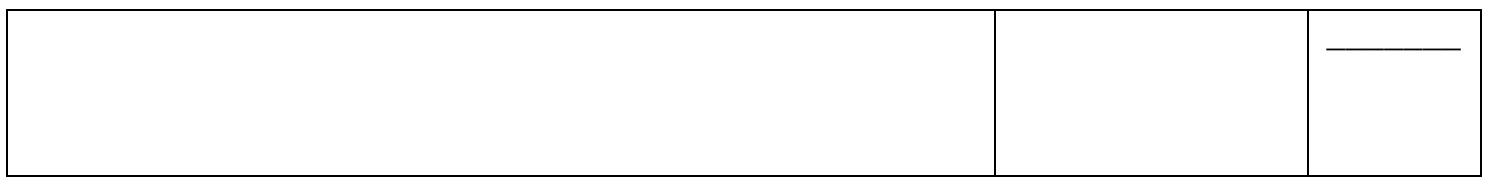

Morse

Fall Scale Score $=$ Total 


\section{Morse Fall Scale Variable Descriptions and Scoring Hints}

\section{History of falling}

- This is scored as 25 if the patient has fallen during the present hospital admission or if there was an immediate history of physiological falls, such as from seizures or an impaired gait before admission. If the patient has not fallen, this is scored 0 . Note: If a patient falls for the first time, then his or her score immediately increases by 25 .

2. Secondary diagnosis - This is scored as 15 if more than one medical diagnosis is listed on the patient's chart; if not, score 0 .

\section{Ambulatory aid}

- This is scored as 0 if the patient walks without a walking aid (even if assisted by a nurse), uses a wheelchair, or is on bed rest and does not get out of bed at all. If the patient uses crutches, a cane, or a walker, this variable scores 15; if the patient ambulates clutching onto the furniture for support, score this variable 30 .

\section{IV or IV Access}

- This is scored as 20 if the patient has an intravenous apparatus or a saline/heparin lock inserted; if not, score 0 .

\section{Gait}

- The characteristics of the three types of gaits are evident regardless of the type of physical disability or underlying cause.

1. A normal gait is characterized by the patient walking with head erect, arms swinging freely at the side, and striding without hesitation. This gait scores 0 .

2. With a weak gait (score10), the patient is stooped but can lift the head while walking without losing balance. If support from furniture is required, this is with a featherweight touch for reassurance, rather than grabbing to remain upright. Steps are short and the patient may shuffle.

3. With an impaired gait (score 20), the patient may have difficulty rising from the chair, attempting to get up by pushing on the arms of the chair, and/or bouncing (i.e., by using several attempts to rise). The patient's head is down, and he or she watches the ground. Because the patient's balance is poor, the patient grasps onto the furniture, a support person, or a walking aid for support and cannot walk without this assistance. Steps are short and the patient shuffles.

4. If the patient is in a wheelchair, the patient is scored according to the gait he or she used when transferring from the wheelchair to the bed.

\section{Mental status}

- When using this Scale, mental status is measured by checking the patient's selfassessment of his or her own ability to ambulate. Ask the patient, "Are you able to go to the bathroom alone or do you need assistance?" If the patient's reply judging his or her ability is consistent with the activity order on the Kardex, the patient is rated as 
"normal" and scored 0 . If the patient's response is not consistent with the activity order or if the patient's response is unrealistic, then the patient is considered to overestimate his or her abilities and to be forgetful of limitations and is scored as 15.

\section{Fall Risk}

- Use the Morse Fall Scale Score to see if the patient is in the low, medium, or high-risk level. (See the "Fall Risk Level" table below to determine the level and the action to be taken.)

- Implement the interventions that correspond with the patient's fall risk level. (See "Fall Risk Prevention Interventions" below.)

- Use the Morse Fall Scale Score to see if the patient is in the low, medium, or high-risk level. (See the "Fall Risk Level" table below to determine the level and the action to be taken.)

\section{Level}

\begin{tabular}{|l|c|l|}
\hline Risk Level & Morse Fall Scale Score & Action \\
\hline Low Risk & $0-24$ & Implement Low-Risk Fall Prevention Interventions \\
\hline Medium Risk & $25-44$ & Implement Medium Risk Fall Prevention Interventions \\
\hline High Risk & 45 and higher & Implement High-Risk Fall Prevention Interventions \\
\hline
\end{tabular}

UTHCT previously attained approval to use the tool. This tool is part of the computer system.

\section{Appendix H}

Fall Rate Tool

\begin{tabular}{|c|c|c|}
\hline $\begin{array}{c}\text { Number of } \\
\text { Falls Last } 30 \\
\text { days }\end{array}$ & $\begin{array}{c}\text { Number of } \\
\text { Falls Last } 60 \\
\text { days }\end{array}$ & $\begin{array}{c}\text { Number of patients that sustained a fall and was identified as fall Risk } \\
\text { With Morse Fall Scale } \\
\text { X=last } 30 \text { days } \\
Y=\text { Last } 60 \text { days }\end{array}$ \\
\hline 11 & 20 & $\begin{array}{c}X= \\
Y=\end{array}$ \\
\hline
\end{tabular}




\begin{tabular}{|c|c|c|c|c|c|c|c|c|}
\hline $\begin{array}{l}\text { Number of Falls } \\
\text { Using EPFRAT }\end{array}$ & $\begin{array}{c}\text { Week } \\
1\end{array}$ & $\begin{array}{l}\text { Week } \\
2\end{array}$ & $\begin{array}{c}\text { Week } \\
3\end{array}$ & $\begin{array}{c}\text { Week } \\
4\end{array}$ & $\begin{array}{c}\text { Week } \\
5\end{array}$ & $\begin{array}{c}\text { Week } \\
6\end{array}$ & $\begin{array}{c}\text { Week } \\
7\end{array}$ & $\begin{array}{c}\text { Week } \\
8\end{array}$ \\
\hline $\begin{array}{l}\text { Number of } \\
\text { patients that } \\
\text { were identified } \\
\text { as a fall risk } \\
\text { with EPFRAT } \\
\text { and sustained a } \\
\text { fall }\end{array}$ & & & & & & & & \\
\hline $\begin{array}{l}\text { Total Number } \\
\text { of falls }\end{array}$ & & & & & & & & \\
\hline $\begin{array}{l}\text { Total number of } \\
\text { falls in } 30 \text { days } \\
\text { and at } 60 \text { days } \\
X=30 \text { days } \\
Y=60 \text { days }\end{array}$ & \multicolumn{4}{|c|}{$X=$} & \multicolumn{4}{|c|}{$Y=$} \\
\hline
\end{tabular}

\begin{tabular}{|c|c|c|c|}
\hline $\begin{array}{c}\text { Gender of the patient } \\
\text { that fell }\end{array}$ & AGE & EPFRAT Score & Injury $Y / N$ ? \\
\hline & & & \\
\hline & & & \\
\hline & & & \\
\hline & & & \\
\hline & & & \\
\hline & & & \\
\hline & & & \\
\hline & & & \\
\hline & & & \\
\hline $\begin{array}{c}\text { Gender of the patient } \\
\text { that fell }\end{array}$ & AGE & EPFRAT Score & Injury $\mathrm{Y} / \mathrm{N}$ ? \\
\hline & & & \\
\hline & & & \\
\hline & & & \\
\hline & & & \\
\hline & & & \\
\hline
\end{tabular}




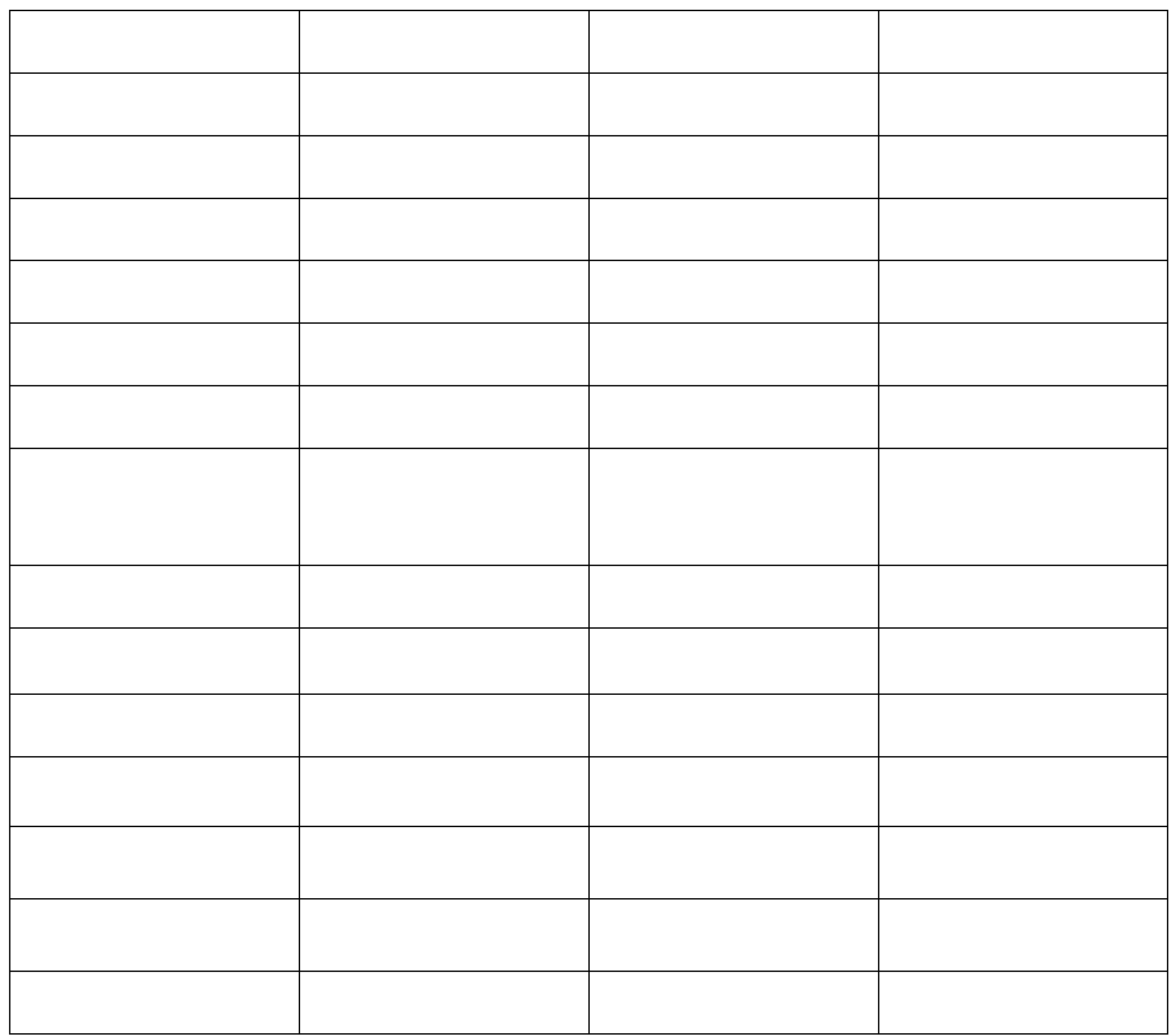

\section{APPENDIX I}

\section{Fall Risk Assessment Process}

1) Fall Risk Assessment using the Edmonson psychiatric Fall Risk Assessment Tool (EPFRAT)

a) Assessments completed consistently

b) Upon admission

c) Daily 
d) With a change in patient condition

e) Discharge

i) Education with the patient begins on admit and is carried on throughout the stay

(1) Use call light

(2) Communicate Needs to the Nurse

(3) Keep the room tidy with nothing left on the floor

(4) Make sure to wear eyewear when out of bed

(5) Make sure to use an assistive device when ambulating

2) For any patient scoring $\geq 90$ on the EPFRAT

a) Meet with nurse, patient care associates (PCA), charge nurse, patient, and family (if available)

i) Discuss risk factors ii) Ask necessary questions

(1) Are you in pain?

(2) How is your vision?

(3) Are you sleeping well?

(4) Are you eating well?

(5) Why do you fall?

3) The nurse, charge nurse, PCA, patient, and family (if available)can use all collected data to implement the following changes to the care plan. In some cases, changes not mentioned may be necessary. a) History of falls

i) Make sure all items in reach ii)

Keep walkways clear iii) Teach

patient to call for help iv) Tell

patient not to get up alone

b) Dangerous medications or medication side effects

i) Medication review ii) Bedside commode/bed pain

iii) Attempt dose reductions

c) Needs ambulation aid

i) Make sure the patient has the appropriate ambulation aid (crutches, cane, walker, wheelchair

ii) Ambulation aid is within reach

d) The patient is attached to an IV pole or another medical device

i) Call for assistance ii) Call light within reach

iii) Bedside commode or assist to the restroom

e) Unsteady gait 
i) Provide ambulation aid that is appropriate such as a walker or wheelchair ii) Patient to ask for assistance

f) Cannot remember asking for help

i) Bed alarms ii) Q 15-minute rounding

iii) Ask family to visit as often as possible and let the nurse know when you are in the room

4) The nurse will oversee completing the EPFRAT and initiation of the care plan revision with the above-listed group. 